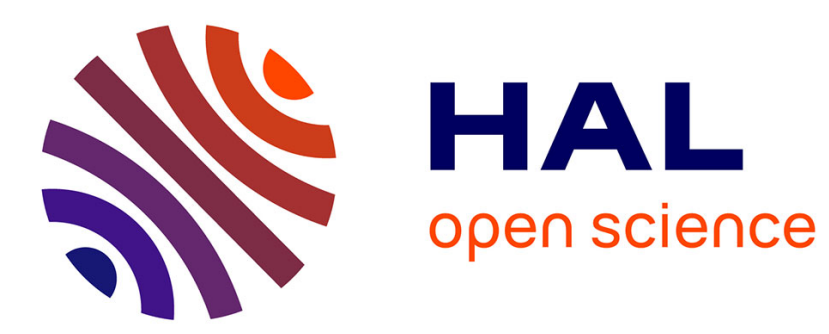

\title{
Do migrants transfer productive knowledge back to their origin countries?
}

Jérôme Valette

\section{To cite this version:}

Jérôme Valette. Do migrants transfer productive knowledge back to their origin countries?. 2017. halshs-01425451

\section{HAL Id: halshs-01425451 \\ https://shs.hal.science/halshs-01425451}

Preprint submitted on 3 Jan 2017

HAL is a multi-disciplinary open access archive for the deposit and dissemination of scientific research documents, whether they are published or not. The documents may come from teaching and research institutions in France or abroad, or from public or private research centers.
L'archive ouverte pluridisciplinaire HAL, est destinée au dépôt et à la diffusion de documents scientifiques de niveau recherche, publiés ou non, émanant des établissements d'enseignement et de recherche français ou étrangers, des laboratoires publics ou privés. 


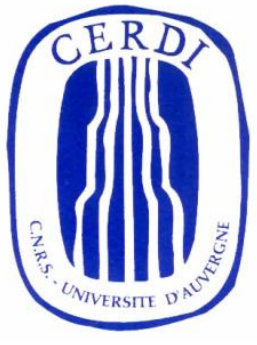

CENTRE D'ETUDES

ET DE RECHERCHES

SUR LE DEVELOPPEMENT

INTERNATIONAL

\title{
SÉRIE ÉTUDES ET DOCUMENTS
}

\section{Do migrants transfer productive knowledge back to their origin countries?}

\author{
Jérôme Valette
}

Études et Documents $\mathrm{n}^{\circ} 22$

December 2016

To cite this document:

Valette J. (2016) "Do migrant transfer productive knowledge back to their origin countries?", Études et Documents, $n^{\circ} 22$, CERDI.

http://cerdi.org/production/show/id/1835/type production id/1

\section{CERDI}

65 BD. F. MITTERRAND

63000 CLERMONT FERRAND - FRANCE

TEL. + 33473177400

$\mathrm{FAX}+33473177428$

www.cerdi.org 


\section{The author}

Jérôme Valette

PhD Student in Economics

CERDI - Clermont Université, Université d'Auvergne, UMR CNRS 6587, 65 Bd F. Mitterrand, 63009 Clermont-Ferrand, France.

E-mail: jerome.valette@udamail.fr

This work was supported by the LABEX IDGM+ (ANR-10-LABX-14-01) within the program "Investissements d'Avenir" operated by the French National Research Agency (ANR).

Études et Documents are available online at: http://www.cerdi.org/ed

Director of Publication: Vianney Dequiedt

Editor: Catherine Araujo Bonjean

Publisher: Mariannick Cornec

ISSN: 2114 - 7957

\section{Disclaimer:}

Études et Documents is a working papers series. Working Papers are not refereed, they constitute research in progress. Responsibility for the contents and opinions expressed in the working papers rests solely with the authors. Comments and suggestions are welcome and should be addressed to the authors. 


\begin{abstract}
This paper analyses whether international migrants contribute to foster innovation in developing countries by inducing a transfer of productive knowledge from destination to the migrants' home countries. Using the Economic Complexity Index as a proxy for the amount of productive knowledge embedded in each countries, and bilateral migrant stocks to 20 OECD destination countries, we show that international emigration is a strong channel of technological transmission. Diasporas foster the local adoption of new technologies by connecting high technology countries with low ones, reducing the uncertainty surrounding their profitability. Our empirical results support the fact that technological transfers are more likely to occur out of more technologically advanced destinations and when emigration rates particularly high.
\end{abstract}

\title{
Keywords
}

International migration, Technology transfer, Export sophistication, Diaspora externalities.

\section{JEL codes}

F22, O33, F63.

\section{Acknowledgment}

I would like to thank Simone Bertoli, Jean-Louis Combes, Frédéric Docquier, Anne Viallefont, Yves Zenou, the participants at the first Ph.D. Workshop on the Economics of Migration in Southampton and the seminar participants at CERDI for very helpful comments and fruitful discussions. All remaining errors are my own responsibility. 
"Accumulating productive knowledge is difficult. For the most part, it is not available in books or on the internet. It is embedded in brains and human networks." (Hausmann et al., 2011, p. 7)

\section{Introduction}

The Venetian travel merchant Marco Polo spent 24 years in Asia at the end of the $13^{\text {th }}$ century, describing his travels in The Book of the Marvels of the World, which allowed Europeans to discover a number of Chinese innovations-such as paper money, the use of the coal or eyeglasses-that were then adopted. Although the information about the existence of new technologies certainly spreads today more easily than at the times of Marco Polo, this needs not to translate immediately into its local adoption, which represents the main form of innovation in developing countries (World Bank, 2008). The returns from a local adoption are uncertain, and no legal protection is granted to the entrepreneurs that succeed in adopting a foreign technology, so that other domestic producers can rapidly erode the ensuing profits, so that there is an under-provision of entrepreneurial efforts which are required for the adoption of foreign technologies (Hausmann and Rodrik, 2003).

This paper analyzes whether international migrants can contribute to foster innovation in developing countries, as they could help reducing the uncertainty surrounding the profitability of a local adoption of foreign technologies. Indeed, international migration can facilitate the transfer of technologies from the North to the South, by connecting high technology countries with low ones. Diasporas and emigrants are directly in touch with what is produced in developed countries and can act as scouts, exploring all the production possibilities for their origin country. They can more easily understand which technologies are suitable for local adoption and which are not, lifting the veil on the cost structure of their origin country. To the best of our knowledge, the first empirical evidence of international knowledge diffusion at the country level was raised by Coe and Helpman (1995) who underlined the positive correlation between foreign $\mathrm{R} \& \mathrm{D}$ capital and the total factor productivity. More recently, Bahar et al. (2014) have shown that a country is 65 percent more likely to add a new product to its export basket if a neighbouring country already exports this product. While not testing for the channels trough which knowledge is spread across nations, Bahar et al. (2014) mention that trade, FDI and migration have certainly a role to play in that process. In this paper we investigate empirically this major issue, focusing on the role of international migration. We use the Economic Complexity Index as a proxy for innovation and productive knowledge embedded in each economy. We focus on the ECI as an indicator of technology since it encompasses the large definition of knowledge not only taking into 
account explicit but also tacit knowledge which is both harder to transfer and more likely to hamper the growth of countries (Hidalgo et al., 2007). This measure allows us to capture possible knowledge spillovers between products since proximity between goods matters, and that capabilities required for one product are useful in many other different productions. To address endogeneity issues, we rely on the System GMM estimator (Blundell and Bond, 1998) which allows us to deal with identification issues of our variable of interest but also of the other covariates. We use alternatively internal and external instruments using the predictions of a pseudo-gravity regression that includes interactions between year dummies and the geographic distances between each destination-origin pairs (see Feyrer (2009)). Our results show that international migrants foster the local adoption of foreign technology at origin. We also provide evidence that our main results are not driven by trade, FDI and geographical or genetic distance and that they are robust to different technological indicators.

The present paper brings together and contribute to two main strands of literature which are first, the determinants of the technological diffusion and second, the transfers of norms and ideas across countries, induced by the international migration. The first literature highlights the diffusion of technologies across borders in response to international human mobility. For instance, Kerr (2008) shows that diasporas strongly influence the international technology diffusion. Indeed his results point out that an increase of 10 percent for a given country of its researchers residing in the US, is associated with a one percent increase in the foreign output. His model supports the idea that scientists abroad ease the diffusion of knowledge to "technology follower's economies" and then, spur the process of imitation. Similar results are presented by Mayr and Peri (2009) with a special look on return migration and by Andersen and Dalgaard (2011) who show that the intensity of temporary movements of workers is a very good predictor of global productivity levels. In the same way, Naghavi and Strozzi (2015) concentrate their study on 34 developing countries and study the interaction between emigration and innovation performances, measured with granted patents. They show that diasporas create new source of knowledge for domestic innovators under sound intellectual property rights in the origin country. Moreover, they find that this positive inflow of knowledge overcome the direct loss from those who left the country. At the micro level, Agrawal et al. (2011), using patent citation data from Indian inventions, show also that diasporas abroad help to maintain access for inventors to a foreign existing source of knowledge and spur therefore innovation in the origin country. As far as the emergence of global inventor teams is concerned, Miguélez (2016) and Kerr and Kerr (2015) study the rise in international migration which increases co-patenting and fosters the transmission of technology from devel- 
oped to developing countries. Finally, Bahar and Rapoport (2016), the closest paper to our analysis, tests the hypothesis of knowledge diffusion through international migration with an analysis at the product level (UNComtrade data from 1984 to 2010 at the 4-digit Standard International Trade Classification). With this high level of disaggregation, they find that migration, ahead of trade and Foreign Direct Investments, is a strong driver of the evolution of comparative advantage. An increase of 10 percent in the migrant stock at destination is associated with a three percent increase in the probability to export one product for which the destination country has already a comparative advantage. Our paper enables us, using a more aggregate analysis, to capture additional indirect effects of migration on the development of new comparative advantages. Indeed, we allow migrants' origin countries to develop new comparative advantages not only in products for which migrants' host countries have a comparative advantage but also in products that require close productive knowledge. For instance, migrants residing in a country that exports cars (SITC 781.2) could help promoting the development of the exports by the origin country of closely related products, such as motor cycles (SITC 785.1) or accessories of motor vehicles (SITC 784.3), an effect that goes beyond the one identified by Bahar and Rapoport (2016).

The second literature related to our paper is the literature on the "transfer of norms" started with the seminal paper of Spilimbergo (2009) who studies the diffusion of democracy through international students. Norms transferred by international migrants can refer to politics (Spilimbergo, 2009; Docquier et al., 2016; Omar Mahmoud et al., 2013), fertily rates (Beine et al., 2013; Bertoli and Marchetta, 2015) or gender norms for example (Tuccio and Wahba, 2016; Lodigiani and Salomone, 2012). In the case of technology transfers, Lodigiani (2008) shows for instance that high-skill migrants positively influence the productivity in their origin country. An increase in emigration rates fosters the productivity at home. We borrow to this literature its main specifications and the calculation of the technological norm to which each economy is exposed.

The remainder of the paper is organized as follows. Section 2 discusses the data that we use, first looking at the Economic Complexity Index, and second focusing on international migration data. Then, we bring to light some stylized facts in international migration flows and technology levels. We show that the recent technology convergence is possibly associated with changes in international migration patterns. Section 3 presents our empirical specification and all the challenges associated with it. Section 4 outlines the baseline results and section 5 provides some robustness checks. Finally, section 6 develops concluding remarks. 


\section{Data}

In this section we describe the data we use. We start with international migration data and then, move to the technology variable: the Economic Complexity Index. ${ }^{1}$

\section{$2.1 \quad$ Emigration data}

A growing empirical literature has emerged recently as a result of the availability of new migration data. We take advantage of these new databases and use the IAB brain-drain database developed by Brücker et al. (2013), which decomposes the stocks of migrants (defined as foreign-born individuals) to 20 OECD countries. These destination countries are Australia, Austria, Canada, Chile, Denmark, Finland, France, Germany, Greece, Ireland, Luxembourg, Netherlands, New Zealand, Norway, Portugal, Spain, Sweden, Switzerland, United Kingdom, and the United States. Using only 20 destination countries could be problematic since we ignore half of total world migration. However these 20 OECD countries represent 85 percent of the total migration for high skilled. In this paper, emigration rates are defined as the share of migrants (25 years and above) in the pre-emigration population. Unfortunately, several limits emerge from migration data. It is worth noting that, although we use stocks, ideally researchers would be interested in flows that reflect the dynamics of the migration process. Indeed, some of the people belonging to a diaspora, like retired workers for instance, do not play a huge role in all the transfers that can occur to their origin country; and particularly when we look at technological transfer. Moreover we know that the evolution over time of these stocks reflects some demographic events that are unrelated to migration like death or return migration for example. Another limit, is the omission of illegal migrants who are not present in census aside from high skill migrants who mainly use legal channels in order to change their country of residence. We detail further some stylized facts related to recent international migration changes.

\subsection{How to measure export sophistication? The Economic Com- plexity Index}

In the long tradition of growth theories, Hausmann et al. (2007) have tried to understand whether countries specialising in higher productivity goods grow faster. Particularly, they have focused their attention on the sophistication of export baskets with a special look on

\footnotetext{
${ }^{1}$ Definitions, sources and statistics of all other variables can be found in the Appendix Table A1.
} 
the evolution of revealed comparative advantage (RCA thereafter). This concept, developed by Balassa (1965), defines that a country $c$ has a RCA in a product $p$ only if this country exports $p$ in larger proportions than the share of $p$ in the world trade and is computed as:

$$
R C A_{c p} \equiv \frac{x_{c p}}{\sum_{c} x_{c p}} / \frac{\sum_{p} x_{c p}}{\sum_{c p} x_{c p}}
$$

where $x_{c p}$ is the monetary value of $p$ exported by country $c$. Using the notion of revealed comparative advantage, Ricardo Hausmann and his co-authors have developed two main measures of export complexity for countries. First, Hausmann et al. (2007) construct a proxy for what they call the productivity level associated with a country's exports (EXPY). ${ }^{2}$ This index is based on the underlying hypothesis that higher income countries export goods with higher productivity levels. The first drawback of this indicator is that it is computed using GDP per capita and thus, presents a strong correlation with this last. The second drawback is that it does not take into account proximity between goods. Nevertheless, we know that productive knowledge required for a given product helps to the production of a similar product. These two limitations explain why Hidalgo and Hausmann (2009) recently shifted the discussion from productivity level to underlying capabilities that are required to produce a particular good. Indeed, in order to explain growth differences, the literature about export sophistication now makes reference to a new indicator: the Economic Complexity Index (ECI thereafter). In this way, Ricardo Hausmann and his co-authors write that "countries do not simply make the products and services they need. They make the ones they can" (Hausmann et al., 2011, p. 18). Using the ECI, the level of sophistication of a product is no longer based on the income of its exporters but on the different capabilities that it requires. Each economy can therefore be summarized through its number of available capabilities. It is worth observing that in each framework, EXPY or ECI, the authors keep the assumption that the amount of productive knowledge embedded in each country can be approximated by simply looking at national production and exports.

The ECI is built starting with a network representation of the international trade where countries are connected to tradable products, using the concept of revealed comparative advantage. ${ }^{3}$ Countries and products (vertices) form the two independent vertex $C$ and $P$ of a bipartite graph $G=(C, P)$. This network can be represented through the $M_{c p}$ matrix

\footnotetext{
${ }^{2}$ Hausmann et al. (2007) compute first PRODY an index which represents, for each product, the weighted income level associated with exporters of this product. Then, they compute EXPY as the export-weighted average of PRODY values for products exported by each country.

${ }^{3}$ Trade data are based on the 4-digit Standard International Trade Classifications comprising over 700 commodities.
} 
where each element is equal to one if the country $c$ as a revealed comparative advantage in the product $p$, and zero otherwise. This matrix writes as:

$$
M_{c p} \equiv\left\{\begin{array}{l}
1 \text { if } R C A_{c p} \geq 1 \\
0 \text { otherwise }
\end{array}\right.
$$

The ECI is then computed on the basis of two different dimensions. First, Diversity wich is the number of distinctive products exported by a country. The more a country has a large panel of capabilities, the more it is able to export a diversified set of goods. Diversity is defined as:

$$
\text { Diversity }_{c}=\boldsymbol{k}_{0}^{c} \equiv M_{c p} \mathbf{1}
$$

where $\mathbf{1}$ is a column vector, whose elements are all equal to one. The second dimension in the ECI is the ubiquity. Ubiquity is a measure of sophistication that gives the number of countries $c$ which export a given product $p$. A complex economy is then an economy which exports products that are exported only by itself or by a small number of countries. Ubiquity is defined as:

$$
\text { Ubiquity }_{p}=\boldsymbol{k}_{0}^{p} \equiv \mathbf{1}^{\prime} M_{c p}
$$

where $\mathbf{1}^{\prime}$ is the transpose of the vector $\mathbf{1}$. If we refer to the graph theory we can say that $\boldsymbol{k}_{0}^{c}$ and $\boldsymbol{k}_{0}^{p}$ are the degree of each vertex in the bipartite graph $G=(C, P)$, i.e., the number of incident paths coming from the other vertices. It is worth noticing that each dimension, namely Ubiquity and Diversity, is affected by the existence of rare capabilities. Determining if ubiquity is the result of complexity or scarcity, for instance, is then problematic. As a matter of fact, precious stones have a particularly low ubiquity since they are concentrated in few countries. However, exporting precious stones does not reveal anything about the complexity of a country since their extraction does not need complex productive knowledge. Looking at the low diversity of precious stones exporters reveals that the low ubiquity of these last comes from their scarcity. Conversely, the low ubiquity of X-ray machines does not reveal scarcity but the complex productive knowledge that are embedded in. Hausmann et al. (2011) use therefore an iterative process with $N$ steps, called "the method of reflections", where the information on each dimension is used in order to correct the other. Ubiquity is computed with a corrected measure of Diversity and vice versa, such as:

$$
\begin{aligned}
\boldsymbol{k}_{N}^{c} & \equiv\left[\operatorname{diag}\left(\boldsymbol{k}_{0}^{c}\right)\right]^{-1} M_{c p} \boldsymbol{k}_{N-1}^{p} \\
\boldsymbol{k}_{N}^{p} & \equiv\left[\operatorname{diag}\left(\boldsymbol{k}_{0}^{p}\right)\right]^{-1} M_{c p}^{\prime} \boldsymbol{k}_{N-1}^{c}
\end{aligned}
$$


with $M_{c p}^{\prime}$ the transpose of the $M_{c p}$ matrix and $\operatorname{diag}(\boldsymbol{z})$ a diagonal matrix containing the elements of the vector $\boldsymbol{z}$ on its main diagonal and zero elsewhere. The method of reflections can be seen as a Markov process where each $N$ iteration is computed using the information of the previous state $N-1$, and where $\boldsymbol{k}_{0}^{c}$ and $\boldsymbol{k}_{0}^{p}$ are the initial states. A simple way to extract all the information and the iteration processes embedded in the network, in order to obtain a proxy of the productive knowledge available in each economy, is therefore to compute the $\widetilde{M_{c c^{\prime}}}$ matrix which connects each country pair. Indeed, if we insert (6) in (5) we obtain:

$$
\boldsymbol{k}_{N}^{c} \equiv \widetilde{M_{c c^{\prime}}} \boldsymbol{k}_{N-2}^{c}
$$

Each entry of the $\widetilde{M_{c c^{\prime}}}$ matrix represents, for a given country pair, the similarity of countries' export basket with larger weights for less ubiquitous products. This matrix is calculated as:

$$
\widetilde{M_{c c^{\prime}}} \equiv\left[\operatorname{diag}\left(\boldsymbol{k}_{0}^{c}\right)\right]^{-1} M_{c p}\left[\operatorname{diag}\left(\boldsymbol{k}_{0}^{p}\right)\right]^{-1} M_{c p}^{\prime}
$$

It is worth noting that, being the product of two stochastic matrices, $\widetilde{M_{c c^{\prime}}}$ is also a stochastic matrix with the sum of each row equal to one. Interestingly, stochastic matrices have particular properties since their spectral radius is one and their first right eigenvector is a also a vector of ones. In order to compute the ECI, Hausmann et al. (2011) rely therefore on the second right eigenvector of the matrix which correspond to the second largest eigenvalue of the $\widetilde{M_{c c^{\prime}}}$ matrix and which captures the largest amount of variance in the system. Finally, the ECI is the normalized eigenvector $(\vec{K})$ associated with the second largest eigenvalue of $\widetilde{M_{c c^{\prime}}}$ such as:

$$
E C I \equiv \frac{\vec{K}-\overrightarrow{\vec{K}}}{\left(\sigma_{\vec{K}}\right)}
$$

where $\vec{K}$ representing an average, and $\sigma_{\vec{K}}$, the standard deviation of $\vec{K}$. While focusing only on the ECI in this paper, the same way we define it we can also define the Product Complexity Index. Conversely to the ECI which ranks countries, the PCI ranks products regarding their complexity, using the $\widetilde{M_{p p^{\prime}}}$ matrix. This last combines information on the average diversity of countries that export a given product and on the average ubiquity of all the other products that these countries also export. Hausmann et al. (2011) demonstrate that the ECI captures the amount of productive knowledge that is embedded in each country. The ECI reflects both this amount and the capacity of individuals to match those different knowledge, held by distinct people, in the economy. An increase in the ECI of a given country represents therefore either new available knowledge in the economy or better abilities for people to 
match pre-existing knowledge (Process or organizational innovations). However, the way the ECI is defined implies that, developing a revealed comparative advantage in a product, only increases this index if the complexity of the product is larger than the complexity of the country. It means that, if Germany develops a RCA in photographic paper, it will decrease its complexity, as the PCI of photographic paper is lower than its ECI (the opposite is true for Uganda which has an ECI lower than the PCI of this product). It is worth noticing also that the ECI is a relative measure. Indeed, the complexity of each country depends on the complexity of all other economies.

\subsection{Stylized facts}

Figure 1: Average ECI by country from 1980 to 2010

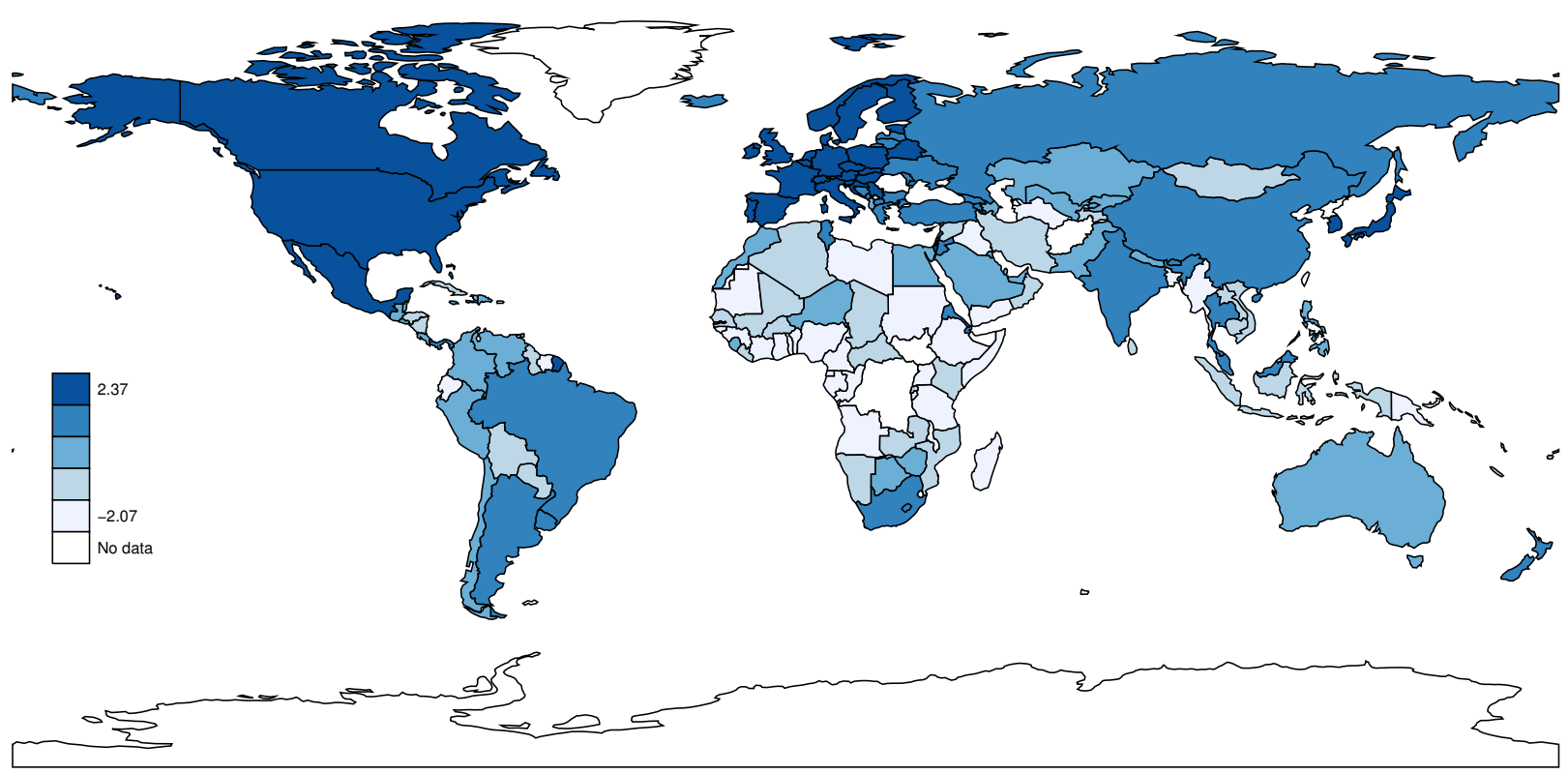

Source: Author's elaboration on Hausmann et al. (2011).

We present here some stylized facts from emigration and technology over the world. Figure 1 presents the distribution of the ECI over the world from 1980 to 2010. ${ }^{4}$ Not surprisingly, we can see that sophisticated exports take place only in few developed countries mainly in North America and Western Europe. Technology and productive knowledge are unequally distributed over the world which leaves scope to technological transfers between countries

\footnotetext{
${ }^{4}$ Post soviet states have here particularly strong average ECI since they only present data between 1992 and 2010 .
} 
with high productive knowledge level to countries with lower ones.

Figure 2: Gaps in technology levels remain strong... but convergence emerges

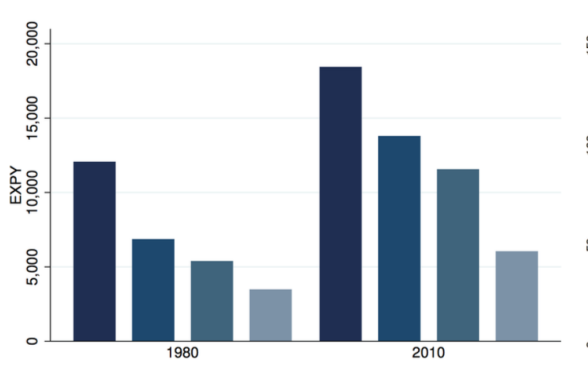

(a) Export sophistication levels (EXPY)

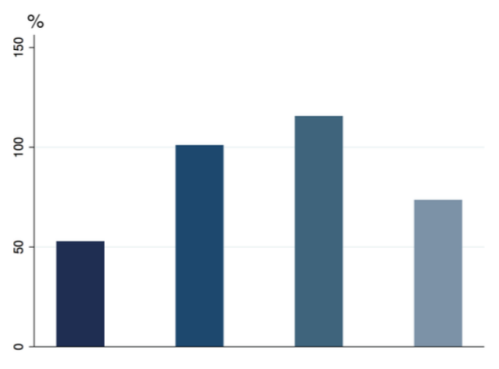

(b) \% change in export sophistication (EXPY)

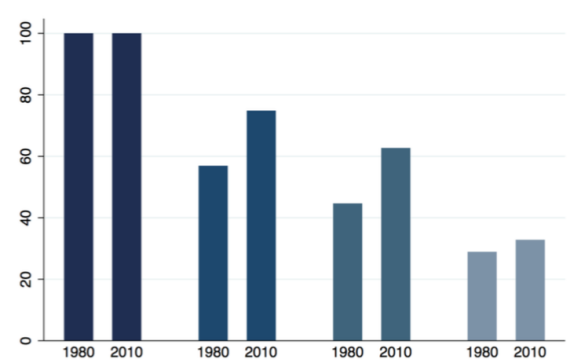

(c) Relative convergence with High-income countries

\begin{tabular}{|l|l|}
\hline High-income & Upper-middle-income \\
\hline Lower-middle-income & Low-income \\
\hline
\end{tabular}

Source: Author's elaboration on United Nations Comtrade database.

In addition, computing a simple relation between the ECI and the GDP shows that the correlation coefficient between the two variables is about 0.75 . There is therefore a big challenge for developing countries to adopt technologies of the North, owing to this strong link between economic complexity and income. However, while this map is informative about technology inequalities, it hides a part of the picture. If we look at export sophistication (EXPY) between 1980 and 2010 we can note some variations in technology achievements over the last decade. Figure 2 shows that, while technology achievement was greater in developed countries [2(a)], between 1980 and 2010, export sophistication grew faster in the developing world [2(b)]. From 1980 to 2000, the EXPY increased twice as much in uppermiddle and lower-middle income countries, than in high-income countries. Even low-income countries have started to achieve a relative convergence to higher export sophistication levels $[2(\mathrm{c})]$. It gives hope for a possible technological convergence between South and North in the future.

As we have already said, migration could play a great role in this relative convergence. According to the UN population division estimates, there was about 200 million migrants in the world (3 percent of the total world population) in 2010. Although, since 1960, the share of migrants to the world population has not really changed, migration patterns are today completely different than 5 decades ago. Indeed, even if international migration has not increased over the last five decades, there were significant changes in its composition. South to North migration is an increasingly important part of the total world migration and has 
increased from 16 to 60 millions of people between 1960 and 2000. What is more interesting is that those emigration flows have changed in their compositions. They are more and more a reflection of high skill migration and of what the literature calls the international brain drain. The number of high-skill migrants residing in OECD countries increased by 70 percent during the 1990s, as opposed to 30 percent for low-skill migrants. Larger and more educated diasporas represent therefore greater opportunities for developing countries that would like to enjoy all of the technologies already developed by the North. These opportunities are even more important since half of all international migrants live in only 10 countries which are, for the most part, leaders in technology. These patterns reinforce our hypothesis that international emigrants might have been a transmission channel of technology from developed to developing countries. Moreover, the transfer of technologies through diasporas is not something merely theoretical. Docquier and Rapoport (2012) summarize researches about the well known example of the Indian diaspora and the development of the IT sector in their origin country. This instance shows how a diaspora (more than a million of Indian migrants living in various developed countries) has been able to capture productive knowledge at destination in order to create new modern industries at home.

\section{Empirical analysis}

We propose in this paper an econometric specification that links the ECI at home with its values in countries where migrants are settled. This specification is borrowed from Lodigiani and Salomone (2012) who study, at the international level, the transfer of gender norms related to political participation. Our estimated equation is:

$$
E C I_{i, t}=\beta_{1} E C I_{i, t-5}+\beta_{2} \overline{E C I}_{i, t-5}+\boldsymbol{\lambda}^{\prime} \boldsymbol{X}_{i, t}+\mu_{i}+\eta_{t}+\varepsilon_{i, t}
$$

where the dependant variable $E C I_{i, t}$ is the economic complexity index in the origin country $i$ at time $t$ and $E C I_{i, t-5}$ its lagged value of five years. $\boldsymbol{X}_{i, t}$ is a vector of controls and $\mu_{i}$ and $\eta_{t}$ are respectively country and time fixed effects whereas $\varepsilon_{i, t}$ is the remaining error term. Our variable of interest is $\overline{E C I}_{i, t-5}$ which is the weighted average value of ECI at destination, i.e. the technological norm to which each country is exposed by its international migrants. It is computed as: ${ }^{5}$

$$
\overline{E C I}_{i, t-5}=\boldsymbol{w}_{t-5}^{\prime} \boldsymbol{E} \boldsymbol{C} \boldsymbol{I}_{j, t-5}
$$

\footnotetext{
${ }^{5}$ Our results are robust to the use of the seminal specification proposed by Spilimbergo (2009). However we prefer the specification of Lodigiani and Salomone (2012) since it reduces the collinearity inherent to an interaction model.
} 
In our baseline specification, the weight vector $\boldsymbol{w}_{t-5}^{\prime}$ represents the emigration rates from $i$ to $j$. Emigration rates are the stock of migrants from the origin country $i$ living in the destination country $j$, overall the total pre-emigration population of $i$. The weight for the origin country itself is zero. $\boldsymbol{E} \boldsymbol{C I}_{j, t-5}$ is the vector of complexity in the 20 OECD destination countries. By construction, the technological norm increases either if the ECI in any destination country increases, or the emigration rate increases to destinations for which the ECI is higher than the average ECI of the 20 OECD destination countries, or both. In robustness we propose other different weight vectors of $\boldsymbol{E} \boldsymbol{C \boldsymbol { I } _ { j , t - 5 }}$. Indeed, we index the weighted average ECI at destination as follows: $\overline{E C I}_{i, t-5}^{\rho}$ where $\rho=I M P, F D I, D I S, G E N$. Each term of $\rho$ represents the average ECI at destination weighted by, trade (imports), FDI inflows, geographical distance and genetic distance respectively. $\beta_{2}$ is our coefficient of interest and gives us the evidence whether international migration acts as a channel of technological transfer from destination to migrant's origin country or not. We test therefore in this paper the hypothesis of a positive and significant $\beta_{2}$. It is worth noting that standards errors are clustered at the country level in order to correct for heteroskedasticity and serial correlation.

$\boldsymbol{X}_{i, t}$ the vector of controls contains for the sending country $i$, the average level of adult's education, the logarithm of the GDP at purchasing power parity per capita, the logarithm of the population (25 years and older), the logarithm of trade openness and Foreign Direct Investment inflows. Hausmann et al. (2007) shows that population, education and income influence positively on export sophistication. Indeed, income is the best predictor of technological levels. There is a virtuous circle between income and the adoption of foreign technologies. In the same way, larger populations induce a larger knowledge diversity (Kuznets, 1960; Simon, 1977), increase the probability to have innovators and foster intellectual networks. Grossman and Helpman (1991) underline also that larger populations increase market's potential and the incentives for individuals to invest in new products. As far as human capital is concerned, education is recognized as a strong determinant for the adoption of new technologies in a society (Arrow, 1962; Romer, 1990; Grossman and Helpman, 1991). It also increases the range of discoverable goods in the framework of Hausmann et al. (2007). We include trade and FDI controls since we know that these international flows can be channels for technological transfers between nations and because they are strongly correlated with migration flows. Foreign-invested firms can directly increase the quality of exports by producing higher quality products, but may also foster the production of higher technology goods in domestic firms (Javorcik, 2004). However, despite these hypothesis, the literature on FDI and knowledge transfers remains non conclusive (Görg and Strobl, 2001). 
Regarding trade, Madsen (2007) shows that trade openness plays positively on international knowledge transmission. In addition, developing countries are more and more exposed to high technology goods particularly if they import large quantities of intermediate goods in response to the world production fragmentation. These products imply automatically an increase in the export sophistication when they are re-exported as finished products $(\mathrm{Xu}$, 2010).

Table 1: Summary statistics

\begin{tabular}{lrrrrr}
\hline Variable & Mean & Std. Dev. & Min. & Max. & N \\
\hline ECI & 0.020 & 1.047 & -2.783 & 2.582 & 600 \\
ECI $_{i, t-5}$ & 0.058 & 0.088 & 0.001 & 0.586 & 600 \\
$\log \left(\right.$ GDP $\left._{i, t}\right)$ & 8.650 & 1.215 & 5.410 & 11.539 & 600 \\
$\log \left(\right.$ Pop $\left._{i, t}\right)$ & 2.675 & 1.427 & -0.690 & 7.184 & 600 \\
$\log \left(\right.$ Trade $\left._{i, t}\right)$ & 4.178 & 0.529 & 2.406 & 6.071 & 600 \\
Hum $_{i, t}$ & 6.932 & 3.066 & 0.535 & 13.27 & 600 \\
$F D I_{i, t}$ & 3.044 & 4.821 & -16.154 & 43.82 & 600 \\
\hline
\end{tabular}

Source: Author's elaboration. ECI is the Economic Complexity Index from Hausmann et al. (2011). $\overline{E C I}_{i, t-5}$ is the weighted average ECI at destination where the weights are the emigration rates computed using Brücker et al. (2013) . GDP $P_{i, t}$ and $P o p_{i, t}$ are respectively the GDP per capita at current PPPs and the total population aged 25 years and older in million taken from the Penn World Table 8.0. $H_{u m} m_{i, t}$ is the average years of schooling attained for population aged 15 and over taken from Barro and Lee (2010). Trade $_{i, t}$ and $F D I_{i, t}$ are respectively the sum of exports and imports of goods and services measured as a share of GDP and the Foreign Direct Investments net inflows in current U.S. dollars from the World Development Indicators.

We follow Hausmann et al. (2011) restricting our analysis only to countries with a population above 1.20 millions between 2008 and $2010 .{ }^{6}$ The sample we estimate is finally composed of 120 countries over the world from 1980 to 2010 with 7 periods of 5 years. ${ }^{7}$ Table 1 describes the distribution of the main variables we use. We observe that the ECI ranges from -2.78 to 2.58. In addition the average of the norm at destination is 0.06 (with a standard deviation of 0.09). The norm is close to zero for countries which have very low emigration rates to OECD destination countries, whereas the norm is higher when emigration rates are more important.

\footnotetext{
${ }^{6}$ As Hausmann et al. (2011), we assume that it is impossible to infer on the export structure of countries that are too small.

${ }^{7}$ Due to the lack of observations, the panel is unbalanced. Table A2 in the Appendix reports the number of observations for each country in the sample.
} 


\subsection{Endogeneity and the System-GMM estimator}

The retained specification evidently suffers from endogenity problems. Our coefficients are almost all affected by simultaneity biases. The level of productive knowledge in a given economy influences its human capital accumulation, its population and evidently its income. Regarding our coefficient of interest, the technological norm at destination, Beine et al. (2013) show three possible bias that emerge in this kind of specification. Indeed, endogeneity of the norm can create some spurious correlations between complexity levels at home and complexity levels at destination. First, the interdependence of the countries' norms generates a reflection problem. Our variable of interest is constructed such that each country's norm includes the complexity of every partners with which it has developed an emigration relation. In the same way, complexity levels of the partners are also influenced by their own norms. It means that, at the global level, each country's complexity level depends on the other country's complexity. Second, migration is not an exogenous phenomenon and the decision to migrate is not random. More precisely, the distribution of migrants from one country across various destinations is influenced by the level of income per capita at origin. In other words, poverty constraints influence the choice of location of migrants. However we know that the level of complexity is highly correlated with the level of GDP per capita in the origin country. There is therefore a reverse causality from the ECI at origin to the norm. This can be easily illustrated by comparing, a developing country, Burkina Faso, which has 80 percent of its migrants in neighbouring Ivory Coast, a low-ECI country, and a developed country, France, for which one of the first migrant's destination is the United-States, a distant technology leader. Third, another problem of endogeneity comes from the fact that emigration and complexity at origin can be jointly influenced by country- and time-specific omitted variables like institutions for example.

Given these identification problems, we rely on the System-GMM estimator developed by Blundell and Bond (1998) which deals with problems of endogeneity in dynamic panel estimates. This estimator is particularly suitable when the lagged dependent variable is included as a regressors, since it makes up for bias in OLS and fixed effects estimators. Indeed, it is worth noting that using a dynamic panel with these two estimators is to some extent problematic. First, OLS estimates are upward biased since the lagged dependent variable is correlated with the individual component of the error term. Second, fixed effects are not more consistent (downward biased) since the within transformation, in the case of samples with small $\mathrm{T}$ and large $\mathrm{N}$, creates a correlation between the error term and the lagged dependent variable (Nickell, 1981). Moreover, the System GMM estimator takes into account 
not only the endogeneity of the variable of interest but all the regressors. It combines in one system the regression in differences (Arellano and Bond, 1991) and the regression in levels (Arellano and Bover, 1995). Differences equations are instrumented with instruments in level and levels equations are instrumented with instrument in differences. Operating in difference permits also to control for unobserved heterogeneity. The overidentification test proposed by Hansen (1982) and the autocorrelation test proposed by Arellano and Bond (1991) confirm or not the validity of the instruments. ${ }^{8}$

A legitimate concern with System GMM arises since this estimator only uses internal instruments for identification. We show, as robustness check, that our results still hold when combining the System GMM estimator with an external instrument generated using the predicted migration stocks obtained from a pseudo-gravity model à la Feyrer (2009). This pseudo-gravity model includes interactions between year dummies and geographic distances between each OECD destination country and each origin country of migrants. These interactions capture therefore all the time-varying effect of distance on migration as the decrease in transportation and communication costs for instance. The gravity equation is defined as:

$$
\log \left(\text { Stock }_{i, j, t}\right)=\beta_{t} \log \left(\text { Dist }_{i, j}\right)+\text { Bord }_{i, j}+\text { Lang }_{i, j}+\text { Colony }_{i, j}+\gamma_{j}+\gamma_{i}+\gamma_{t}+\varepsilon_{i, j, t}
$$

where $\operatorname{Bord}_{i, j}$ is a dummy equal to one if origin country $i$ and destination country $j$ share a common border, $\operatorname{Lang}_{i, j}$ is a dummy equal to one if at least nine percent of the populations of $i$ and $j$ speak a common language, $\gamma_{j}, \gamma_{i}$, and $\gamma_{t}$ are the destination, origin and year fixed effects. In order to address the issue of the large number of zero in migration stocks, we rely on the Poisson pseudo-maximum likelihood estimator (see Santos Silva and Tenreyro, 2006). ${ }^{9}$ Standard errors are clustered at the country pair level.

\section{Results}

Table 2 reports the results of the specification described in the previous section. We first investigate the existence of technological transfers trough migration using OLS in col. 1. Then, we control for unobserved heterogeneity using first year fixed effects in col. 2 and country fixed effects in col. 3. Year fixed effects account for all the time-varying variables that affect similarly the productive knowledge levels of all the countries in our sample. Conversely,

\footnotetext{
${ }^{8}$ We chose to keep the number of instruments below the number of groups in order to remove the problem of instrument proliferation developed by Roodman (2009). All variables, excluding the lagged dependant variable and time fixed effects, are treated as endogenous and are instrumented with their own second lag.

${ }^{9}$ Results of the gravity model are available in the Appendix Table A4.
} 
country fixed effects prevent our estimates to be biased due to the omission of time-invariant countries-specific factors that determine their own levels of complexity. As explained in the previous section, OLS and Fixed-effect are biased when using dynamic panel specification. Thus, we turn to System GMM estimates from col. 4 to 7. It allows us to show that our results are robust when taking into account endogeneity issues. ${ }^{10}$

Pooled OLS and Fixed effects estimates are reported from col. 1 to 3. We first observe that the three regressions support the use of a dynamic panel specification since the lagged dependent variable is positive and highly significant. This highlights a strong persistence in the ECI of countries which has to be taken into account in our analysis. Regarding our coefficient of interest, the Economic complexity at destination, $\overline{E C I}_{i, t-5}$, is always positive and significant at the five percent level. It confirms our testable hypothesis that migrants transfer technology from their destination to their origin country. As far as the other covariates are concerned, human capital, income and population are positively correlated with the levels of productive knowledge in migrants' sending countries. However, while trade openness seems to act as a channel of technological transfer in col. 1 and 2, it is no longer the case when country fixed effects are included. Finally, FDI inflows have no significant impact on the ECI, no matter which estimator is used. It underlines the mixed results shown in the literature on the effect of FDI on export sophistication.

We now turn to our preferred specification using the System GMM estimator in order to correct the endogeneity of all the regressors. As in our previous regressions, the lagged dependent variable is always strongly positive and significant and the ECI is explained at 70 percent by its value five years ago. As expected, the coefficient for the lagged dependent variable in System GMM estimates ranges between the lower (0.167) and the upper bounds (0.778) given by our previous OLS and Fixed effects regressions. Col. 4 reports our baseline result and shows that variations in the economic complexity levels at destination are positively associated with variations in the economic complexity in migrants' home countries. ${ }^{11}$ If migrants transfer productive knowledge to their origin country it appears crucial to establish the extent of this effect. However, interpreting variations in the Economic Complexity Index, which is a relative measure, is not straightforward. Nonetheless, we can compute, using

\footnotetext{
${ }^{10}$ We check for the validity of the estimator in the last rows of the Table 2 . In every columns, we always reject the null hypothesis of first-order serial correlation and do not reject the null hypothesis of no second-order correlation in the residuals. Moreover, the Hansen's J test confirms the overall validity of the instruments. It is important to note that our p-values for this last test are particularly low. It is a great support for the validity of System GMM estimates since Roodman (2009, p. 129) recalls that Hansen test p-values larger than 0.25 have to be seen as potential signs of trouble.

${ }^{11}$ We provide in the Appendix Table A3 the evidence that our baseline result is robust to alternative lag structures either for the lagged dependent variables and other control variables.
} 
Table 2: The effect of ECI at destination on ECI at home; baseline regressions

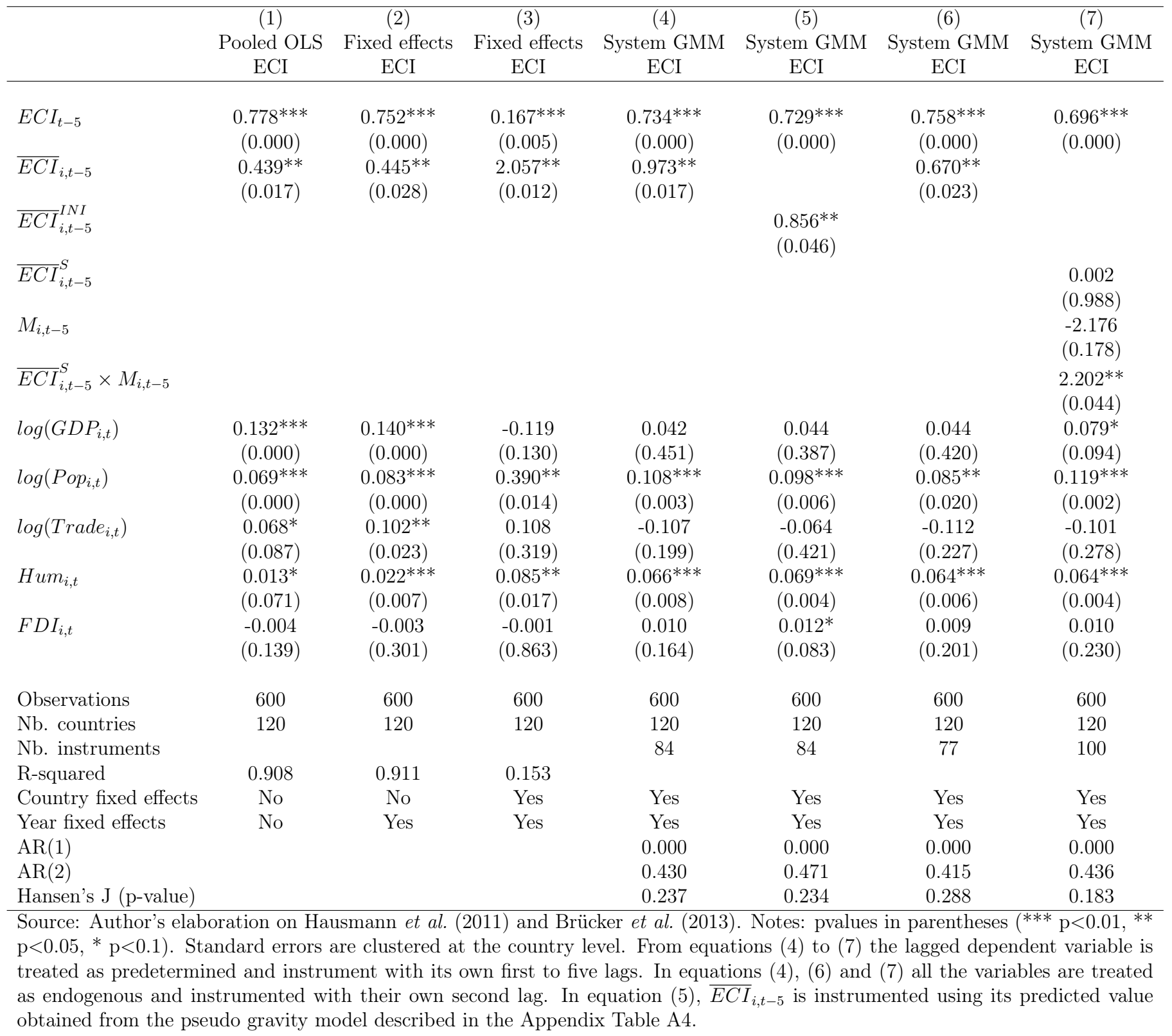

coefficient from col. 4, that an increase of one standard deviation of the technology to which an origin country is exposed through its diaspora increases the economic complexity index at home by 0.09 unit. This seems to be an economically-significant effect despite what has been outlined above. Another problem of interpreting economic complexity variations can come from the fact that our index is computed independently for each year of our period of analysis, between 1980 and 2010. It implies that, changes in the world trade structure may affect the ECI trend, making the interpretation of the indicator variations over time more difficult. In order to control for the possible bias related to the use of the ECI in a dynamic 
framework, Jarreau and Poncet (2012) and Poncet and Starosta de Waldemar (2013) propose to look at the sensitivity of the results using a time-invariant measure of the ECI. ${ }^{12}$ In the same way, we decide to compute the norm at destination using the initial ECI in destination countries in 1980 and no longer the ECI at destination at time $t$ in col. 5. This last estimate means that we keep the amount of productive knowledge constant over the period in our destination countries. It means also that the variability over time of the norm now only comes from the weights vector $\boldsymbol{w}_{t-5}^{\prime}$. The coefficient of $\overline{E C I}_{i, t-5}^{I N I}$ is positive and significant which underlines that removing the dynamic of productive knowledge accumulation at destination does not affect therefore our main result. The amount of technology in receiving countries still influences positively the amount of productive knowledge in migrant's origin countries. Col. 6 reports the results of the System GMM estimator combined with external instruments. It is worth noticing that, while our variable of interest is instrumented using the predicted migration stocks obtained from a pseudo-gravity model à la Feyrer (2009), we still use internal instruments in order to correct for the endogenity of other covariates. Despite a slight decrease in the coefficient we still observe a positive and significant relationship between the weighted technology at destination and the technology at home. The coefficient is in fact not statistically different from the baseline coefficient reported in col. 4 .

Finally we report in col. 7 the robustness of our main result to the use of the seminal specification of Spilimbergo (2009) who studies the relation between international students and the diffusion of democracy over the world. This last estimate is derived from the following equation:

$$
\begin{aligned}
E C I_{i, t} & =\beta_{1} E C I_{i, t-5}+\beta_{2} M_{i, t-5}+\beta_{3} \overline{E C I}_{i, t-5}^{S} \\
& +\beta_{4} \overline{E C I}_{i, t-5}^{S} * M_{i, t-5}+\boldsymbol{\lambda}^{\prime} \boldsymbol{X}_{i, t} \\
& +\mu_{i}+\eta_{t}+\varepsilon_{i, t}
\end{aligned}
$$

As Spilimbergo (2009), we use an interaction model that links the ECI at home with emigration rates $M_{i, t-5}$ and the ECI at destination $\overline{E C I}_{i, t-5}^{S}$. Weights in the norm are no longer emigration rates, as it was with our first specification, but emigration shares. It corresponds to the number of migrants from the origin country $i$ settled in the destination $j$, overall the total number of migrants of $i$. The interaction variable crosses each constitutive terms namely $\overline{E C I}_{i, t-5}^{S}$ and $M_{i, t-5}$. The coefficient in front of the interaction, $\beta_{4}$, gives us the intuition whether emigration rates and ECI at destination play simultaneously on ECI at

\footnotetext{
${ }^{12}$ In these two papers they test the effect of export sophistication on growth, first, using a time invariant measure of export sophistication and then, exploiting the variation of export sophistication over time.
} 
home. ${ }^{13}$ We test here whether this coefficient is positive or not. As expected, the coefficient of the interaction term, in col. 7 , is positive and significant. It shows that the effect of ECI at destination on ECI at home is strengthened when emigration rates increase. We are not

Figure 3: Total effect of ECI at destination and Emigration rates
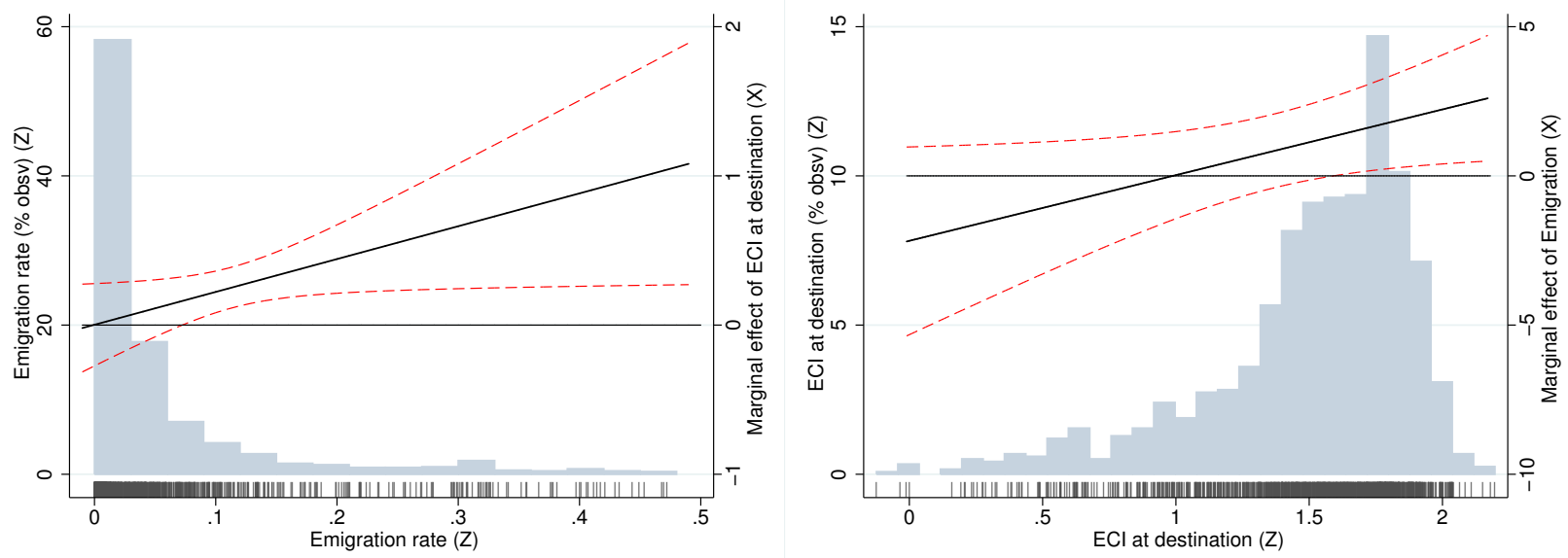

Source: Author's elaboration on Hausmann et al. (2011) and Brücker et al. (2013). Notes: The solid line represents the marginal effect of $\mathrm{X}$ conditional on all values of the modifying variable $\mathrm{Z}$. The histogram indicates the percentage of observations of the modifying variable and each bar on the rug plot represents one observation for this one. The dashed line are respectively the upper and the lower bound of the 95 percent confidence interval.

particularly interested, per se, in the coefficients of the two constitutive terms, $\beta_{2}$ and $\beta_{3}$, since they represent marginal effects for particular values of the conditional variables. By contrast, we plot the total effect of emigration rates and the total effect of the norm at destination for different deciles of the conditional variables. Conditional variables are emigration rates when we look at the total effect of ECI at destination and ECI at destination levels when we look at the total effect of emigration rates. We present these total effects in graphics à la Brambor et al. (2006) in the Figure 3. We observe that the ECI at destination has no effect on the ECI at home when emigration rates are at their lowest levels. However, when emigration rates increase, we observe a positive and significant effect of the technology at destination on the technology in origin countries. This effect is stronger as emigration rates become more an more important. In the same way, emigration rate starts to have a positive and significant effect on the ECI at home only for high levels of technology at destination.

\footnotetext{
${ }^{13}$ We can demonstrate that $\overline{E C I}_{i, t-5}^{S}$ is a transformation of our previous variable of interest $\overline{E C I}_{i, t-5}$ such as: $\overline{E C I}_{i, t-5}=\overline{E C I}_{i, t-5}^{S} * M_{i, t-5}$.
} 
The higher the foreign technology is, the stronger this effect is. The seminal specification of Spilimbergo (2009) supports therefore the intuition of technological transfers trough international migration but highlights that this effect certainly needs high emigration rates, and strong technological levels at destination, to occur.

\section{Robustness checks}

This section first investigates whether our previous results are robust to the introduction of additional control variables and sub-samples. Then we try to evidence some channels of transmission for technological transfer through migration.

\subsection{Additional control variables}

Table 3 reports the results of sub-samples and additional controls. Col. 1 replicates the benchmark results previously estimated in the col. 4 of the Table 2. In col. 2 and 3 we first separate developing and developed countries from the previous sample. In both cases, complexity levels at origin are positively associated with complexity levels in migrants' destination countries. Thus, our previous results are not only driven by developed countries. It is worth noticing also that the higher coefficient for the technological norm inside developed countries suggests that knowledge circulation is stronger among OECD countries compared to the knowledge transfers which occur between high and developing countries. From col. 4 to 8 we introduce a new set of norms in order to dismiss alternative explanations for the technological transfer evidenced in our previous results. More precisely, we modify the weight vector $\boldsymbol{w}_{t-5}^{\prime}$ in our variable of interest $\overline{E C I}_{i, t-5}$, replacing emigration rates by trade, FDI, geographical and genetic distance. ${ }^{14}$ It is important to note that this exercise is particularity challenging given the strong correlations that exist between the different norms computed with different weights. As a matter of fact, Table 4 reports the Pearson correlations between the different norms. As expected these correlations are particularly high even if using immigration rates (for $\overline{E C I}_{i, t-5}$ ) rather than immigration shares (as in $\overline{E C I}_{i, t-5}^{S}$ ) mitigates the problem.

In col. 4 we first weight the ECI of foreign countries using the inverse of the bilateral greatcircle distance between each destination-origin pair. Indeed Bahar et al. (2014) show that knowledge diffusion decreases with geographical distance and that closer countries are more

\footnotetext{
${ }^{14}$ It is worth noticing that this new set of estimate suffers from data constraints which reduces the size of the sample. For instance, genetic distance data are not available for Yemen while FDI data are only available from 1985 and not available for Tajikistan and Turkmenistan.
} 
Table 3: Sub-samples and additional controls

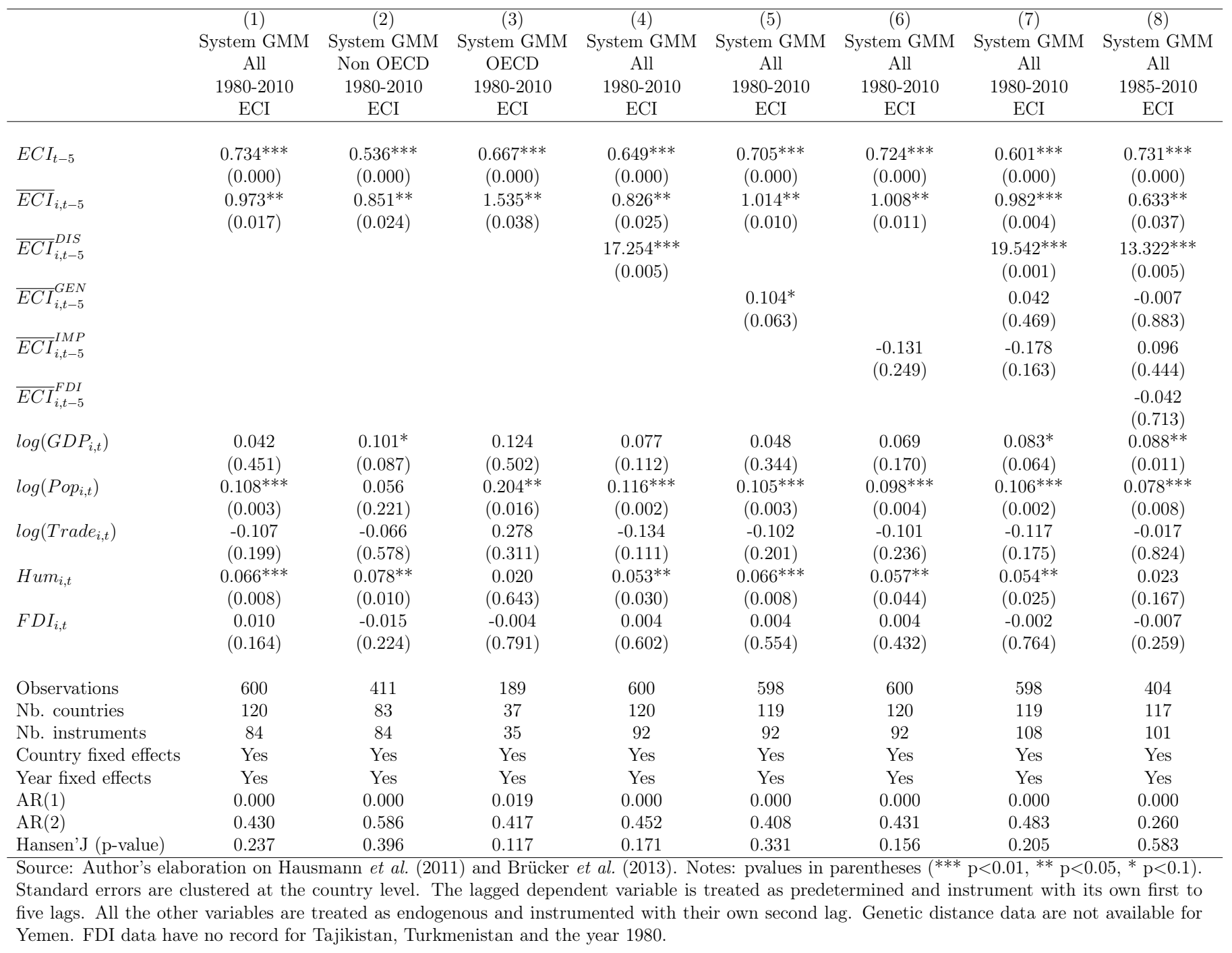

likely to share common technologies. Table 3 reports that the coefficient for the geographical distance weighted average of the ECI at destination $\left(\overline{E C I}_{i, t-5}^{D I S}\right)$ is positive and highly significant which confirms that distance is crucial in technological transfer. The greater the distance between two countries the less technological transfer are important. Interestingly, adding this new control does not affect too much the coefficient for the migration weighted average of the ECI at destination. The effect of $\overline{E C I}_{i, t-5}$ is still positive and significant at the five percent level, while the small decrease in the magnitude suggests that our baseline result was capturing a little part of the distance effect. In col. 5, we replace geographical distance by genetic distance. The rationale to use the inverse of the genetic distance as a weight for technology at destination is given by Spolaore and Wacziarg (2009) who demonstrate that genetic distance acts as barrier to the diffusion of development from the world technological 
Table 4: Correlations between technological norms computed using different weights

\begin{tabular}{lcccccc}
\hline Variables & $\overline{E C I}_{i, t-5}$ & $\overline{E C I}_{i, t-5}^{S}$ & $\overline{E C I}_{i, t-5}^{I M P}$ & $\overline{E C I}_{i, t-5}^{F D I}$ & $\overline{E C I}_{i, t-5}^{G E N}$ & $\overline{E C I}_{i, t-5}^{D I S}$ \\
\hline$\overline{E C I}_{i, t-5}$ & 1.000 & & & & & \\
& & & & & & \\
$\overline{E C I}_{i, t-5}^{S}$ & 0.165 & 1.000 & & & & \\
& $(0.000)$ & & & & & \\
$\overline{E C I}_{i, t-5}^{I M P}$ & 0.149 & 0.583 & 1.000 & & & \\
& $(0.000)$ & $(0.000)$ & & & & \\
$\overline{E C I}_{i, t-5}^{F D I}$ & 0.072 & 0.500 & 0.654 & 1.000 & & \\
& $(0.106)$ & $(0.000)$ & $(0.000)$ & & & \\
$\overline{E C I}_{i, t-5}^{G E N}$ & 0.087 & -0.045 & 0.011 & 0.052 & 1.000 & \\
& $(0.033)$ & $(0.277)$ & $(0.798)$ & $(0.242)$ & & \\
$\overline{E C I}_{i, t-5}^{D I S}$ & 0.205 & -0.020 & 0.134 & 0.152 & 0.616 & 1.000 \\
& $(0.000)$ & $(0.617)$ & $(0.001)$ & $(0.001)$ & $(0.000)$ & \\
\hline
\end{tabular}

Source: Author's elaboration on Hausmann et al. (2011) and Brücker et al. (2013). Notes: pvalues in parentheses. $\overline{E C I}_{i, t-5}^{\rho}$ is the weighted average value of ECI at destination where the weights are respectively emigration shares, imports, FDI and the inverse of genetic and geographical distances with $\rho=$ $S ; I M P ; F D I ; G E N ; D I S$.

frontier. Closer society are more likely to exchange and to learn from each other. As they argue, similarities in term of genetic facilitate the diffusion and the adoption of "complex technological and institutional innovations" (Spolaore and Wacziarg, 2009, p. 471). Here again our main result is robust to the introduction of the $\overline{E C I}_{i, t-5}^{G E N}$ variable. The coefficient for $\overline{E C I}_{i, t-5}$ remains positive and significant at the five percent level. Also, the low significance of $\overline{E C I}_{i, t-5}^{G E N}$ suggests that genetic distance does not play a major role in technological transfer.

In col. 6, we weight the ECI at destination using bilateral trade. Indeed, trade openness captures the fact that, the more a country is trading, the more the latter is exposed to a diversified set of productive knowledge. However, while trade theories predict that openness to trade increases countries' specialization, they underline that this specialization depends on the initial patterns of comparative advantages. A country with comparative advantages in low-technology products will specialize in this kind of goods as it opens its economy to trade and vice versa. We build therefore the variable $\overline{E C I}_{i, t-5}^{I M P}$ which is a bilateral trade weighted average of the ECI at destination. We focus only on imports which permit to the sending country to be in touch with higher technology products. $\boldsymbol{w}_{t-5}^{\prime}$ is now the share that each $j 20$ OECD destination represents in the total imports of the origin country $i$ from these partners. Table 3 shows that the imported ECI is negative while not significant. This sign might reflect 
the fact that importing a large share of products from high-complex economy reflects a strong inability for low ECI countries to produce locally high-technology goods. Still, our variable of interest remains robust to this new control. Col. 7 includes all the previous controls added separately along the previous lines. Despite the inherent problems of collinearity described above our main coefficient remains positive and becomes significant at the one percent level. Finally, in col.8 we add the variable $\overline{E C I}_{i, t-5}^{F D I}$ which is the FDI weighted average of the ECI at destination where the weights are the share that each $j 20$ OECD destination represents in the total FDI that the origin country $i$ receive from all its partners. Due to data limitations the sample is restricted to the period $1985-2010 .{ }^{15}$ Interestingly, migration ahead of trade and FDI seems to be therefore a strong channel of transmission for technology between countries. Despite a slight decrease in the coefficient of $\overline{E C I}_{i, t-5}$, this last remains highly significant at the five percent level. To sum up, Table 3 provides evidence that our baseline result is robust to the introduction of additional control variables and particularly when taking into account trade, FDI, geographical and genetic distances.

\subsection{Alternative channels of transmission}

While the focus in previous section was on changing the weight in our variable of interest, this section tries now to investigates some channels of transmission by changing the second component of the technological norm namely, the indicator of technology at destination. Indeed, we no longer compute $\overline{E C I}_{i, t-5}$ as a weighted average of the ECI at destination but use a different set of variables (in the log-form) which are different proxies for the level of productive knowledge in migrants' destination countries. It is worth noticing that due to collinearity we cannot add these new variables and $\overline{E C I}_{i, t-5}$ in the same regression. While it would have been a suitable way to test for some channels of transmission, this constraint requires us to add separately these variables in different regressions, excluding our variable of interest from these last.

Table 5 reports the results of these new technological norms. Col. 1 replicates our baseline result for comparison. In col. 2 and 3 we first use GDP per capita and TFP as indexes for technology. Indeed, richer countries with higher levels of productivity are more likely to present greater productive knowledge stocks. In both cases the coefficients for the two economic indicators are positive while only significant at the 10 percent level. We also find similar results in col. 4 when we use EXPY an indicator of productivity level to a

\footnotetext{
${ }^{15}$ For comparison, in the same specification as col. 7 i.e without $\overline{E C I}_{i, t-5}^{F D I}$ and over the same time span, the coefficient for $\overline{E C I}_{i, t-5}$ equals to 0.749 and is significant at the five percent level.
} 
country's export basket. This indicator developed by Hausmann et al. (2007) can be seen as a simpler version of the ECI. As explained in section 2, the EXPY is the export weighted average of PRODY values for products exported by each country. PRODY being itself for each product, the weighted income level associated with exporters of this product. Still, the coefficient for the migration weighted average of the EXPY at destination is positive but only significant at the 10 percent level.

Table 5: Channels of transmission

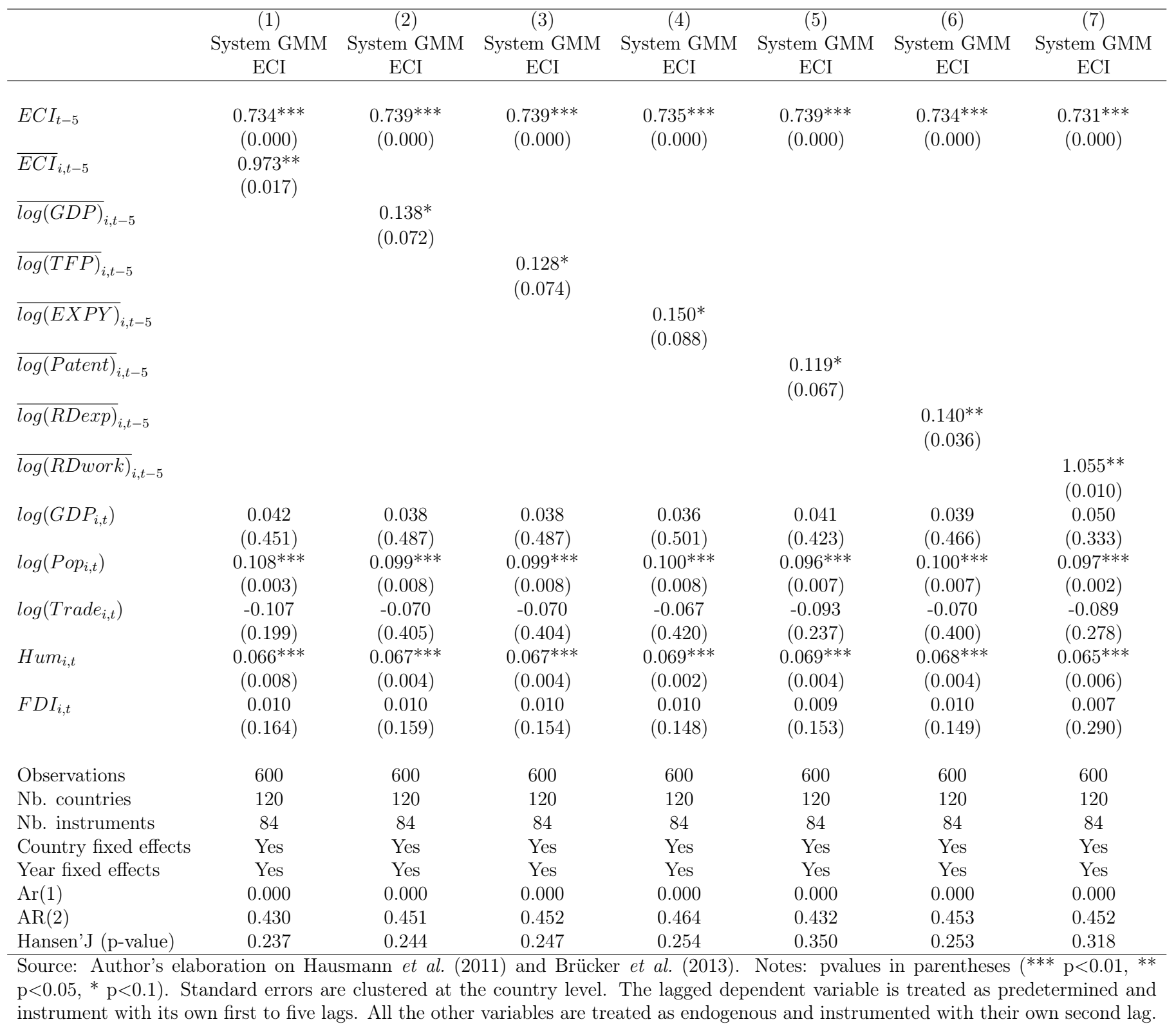

Since traditional economic indicators support the idea of a technological transfer trough migration with low levels of significance we move on innovation indicators from col. 5 to 7 . 
We use sequentially the logarithm of the number of patent applications made by residents, the logarithm of research and development expenditures (in million US dollars) and the logarithm of the number of researcher per 1000 employed as indicators for technology in migrants' destination countries. ${ }^{16}$ While the coefficient for the technological norm computed using patents data is only significant at the 10 percent level, technological norms using indicators of the research sector in destination countries are positive and significant at the five percent level. This highlights the importance of the research sector at destination when it comes to transfer technology to migrants' home countries as first underlined by Kerr (2008).

\section{Conclusions}

Technology has been recognized as one of the main determinants of development. Unfortunately, the distribution of productive knowledge is still unevenly distributed over the world and the majority of regions significantly lag behind in respect of export sophistication. While, the literature about international knowledge diffusion has brought to light the existence of technological spillovers between nations, this paper has focused of one of the possible channels of these technological transfers across countries. It has been shown, using a new strand in the literature, namely the transfers of norms, that international migrants transfer technology from their destination to their country of origin. Using the economic complexity as a proxy for export sophistication and productive knowledge embedded in foreign countries, also allowed us to capture knowledge spillovers in the production of different products. Our results are robust to different estimation methods, to the introduction of different weights in the average ECI at destination and to different technology indicators. Endogeneity issues have been addressed using the System-GMM estimator with internal and external instruments. Moreover, testing the seminal specification proposed by Spilimbergo (2009) we have found that technological transfers are more likely to occur when the intensity of emigration is high and when technology levels in receiving countries are strong. Hausmann et al. (2011) appear therefore to be right when they say that productive knowledge are deeply embedded in brains and human networks. This could be good news for developing countries which could hope, by encouraging close relationships with their diaspora, to overcome the possible brain drain hampering them.

\footnotetext{
${ }^{16}$ Patent data indicators are obtained from the World Development Indicators while other innovation variables are obtained from the OECD Science, Technology and R\&D statistics.
} 


\section{References}

Agrawal, A., Kapur, D. McHale, J. and Oettl, A. (2011). Brain drain or brain bank? The impact of skilled emigration on poor-country innovation. Journal of Urban Economics, 69(1):43-55.

Andersen, T. B. and Dalgaard, C. J. (2011). Flows of people, flows of ideas, and the inequality of nations. Journal of Economic Growth, 16(1):1-32.

Arrow, K. (1962). The economic implications of learning by doing. The Review of Economics Studies, 29(3):155-173.

Arellano, M. and Bond, S. (1991). Some tests of specification for panel data: Monte Carlo evidence and an application to employment equations. The Review of Economic Studies, 58(2):277-297.

Arellano, M. and Bover, O. (1995). Another look at the instrumental variable estimation of error-components models. Journal of Econometrics, 68(1):29-51.

Bahar, D., Hausmann, R., and Hidalgo, C. (2014). Neighbors and the evolution of the comparative advantage of nations: Evidence of international knowledge diffusion? Journal of International Economics, 92(1):111-123.

Bahar, D. and Rapoport, H. (2016). Migration, knowledge diffusion and the comparative advantage of nations. IZA Discussion Papers 9788.

Balassa, B. (1965). Trade liberalisation and "revealed" comparative advantage. The Manchester School, 33(2):99-123.

Beine, M., Docquier, F., and Schiff, M. (2013). International migration, transfer of norms and home country fertility. Canadian Journal of Economics, 46(4):1406-1430.

Bertoli, S. and Marchetta, F. (2015). Bringing it all back home-return migration and fertility choices. World Development, 65:27-40.

Blundell, R. and Bond, S. (1998). Initial conditions and moment restrictions in dynamic panel data models. Journal of Econometrics, 87(1):115-143.

Brambor, T., Clark, W. R., and Golder, M. (2006). Understanding interaction models: Improving empirical analyses. Political Analysis, 14(1):63-82. 
Brücker, H., Capuano, S., and Marfouk, A. (2013). Education, gender and international migration: Insights from a panel-dataset 1980-2010, Mimeo.

Coe, D. T. and Helpman, E. (1995). International R\&D spillovers. European Economic Review, 39(5):859-887.

Docquier, F., Lodigiani, E., Rapoport, H., and Schiff, M. (2016). Emigration and democracy. Journal of Development Economics, 120(1):209-223.

Docquier, F. and Rapoport, H. (2012). Globalization, brain drain, and development. Journal of Economic Literature, 50(3):681-730.

Feyrer, J. (2009). Trade and income: Exploiting time series in geography. NBER working paper No. 14910.

Görg, H., Strobl, E. (2001). Multinational companies and productivity spillovers: A metaanalysis. Economic Journal, 111(475):723-739.

Grossman, G. and Helpman, E. (1991). Innovation and growth in the global economy. Cambridge: MIT Press.

Hansen, L. P. (1982). Large sample properties of generalized method of moments estimators. Econometrica, (p. 1029-1054).

Hausmann, R. and Rodrik, D. (2003). Economic development as self-discovery. Journal of Development Economics, 72(2):603-633.

Hausmann, R. and Rodrik, D. (2005). Self-Discovery in a development strategy for El Salvador. Economia: Journal of the Latin American and Caribbean Economic Association, 6(1):43-102.

Hausmann, R., Hwang, J., and Rodrik, D. (2007). What you export matters. Journal of Economic Growth, 12(1):1-25.

Haussman, R., Hidalgo, C. A., Bustos, S., Coscia, M., Simoes, A., and Yildirim, M. A. (2011). The Atlas of Economic Complexity. Puritan Press. Cambridge MA.

Head, K., Mayer, T., and Ries, J. (2010). The erosion of colonial trade linkages after the independence. Journal of International Economics, 81(1):1-14. 
Hidalgo, C. A. and Hausmann, R. (2009). The building blocks of economic complexity. Proceedings of the National Academy of Sciences, 106(26):10570-10575.

Hidalgo, C. A., Klinger, B., Barabási, A. L., and Hausmann, R. (2007). The product space conditions the development of nations. Science, 317(5837):482-487.

Jarreau, J. and Poncet, S. (2012). Export sophistication and economic growth: Evidence from China. Journal of Development Economics, 97(2):281-292.

Javorcik, B. (2004). Does Foreign Direct Investment increase the productivity of domestic firms? In search of spillovers through backward linkages. American Economic Review, 94(3):605-608.

Kerr, S. P. and Kerr, W. R. (2015). Global collaborative patents. NBER Working Paper 21735 .

Kerr, W. R. (2008). Ethnic scientific communities and international technology diffusion. The Review of Economics and Statistics, 90(3):518-537.

Kuznets, S. (1960). Population change and aggregate output. In Demographic and economic change in developed countries. Columbia University Press. (p. 324-351).

Lodigiani, E. (2008). Diaspora externalities and technology diffusion. Economie Internationale, 115(3):43-64.

Lodigiani, E. and Salomone, S. (2012). Migration-induced transfers of norms: The case of female political empowerment. IRES Discussion Papers 2012-1.

Madsen, J. B. (2007). Technology spillover through trade and TFP convergence: 135 years of evidence for the OECD countries. Journal of International Economics, 72:464-480.

Mayr, K. and Peri, G. (2009). Brain drain and brain return: Theory and application to Eastern-Western Europe. The BE Journal of Economic Analysis $\&$ Policy, 9(1):1-52.

Miguélez, E. (2016). Ethnic scientific communities and the internationalization of technology. (forthcoming in World Bank Economic Review)

Naghavi, A. and Strozzi, C. (2015). Intellectual property rights, diasporas, and domestic innovation. Journal of International Economics, 96(1):150-161.

Nickell, S. (1981). Biases in dynamic models with fixed effects. Econometrica, 49:1471-1426. 
Omar Mahmoud, T., Rapoport, H., Steinmayr, A., and Trebesch, C. (2013). The effect of labor migration on the diffusion of democracy: evidence from a former Soviet Republic. CReAM Discussion Paper Series 1320, Department of Economics, University College London.

Özden, Ç., Parsons C. R., Schiff, M., Walmsley, T. L. (2011). Where on earth is everybody? The evolution of global bilateral migration 1960-2000. World Bank Economic Review, $25(1): 12-56$.

Poncet, S. and Starosta de Waldemar, F. (2013). Export upgrading and growth: The prerequisite of domestic embeddedness. World Development, 51:104-118.

Ratha, D. and Shaw, W. (2007). South-South migration and remittances. World Bank Working Paper 102, World Bank, Washington, DC.

Romer, P. M. (1990). Endogenous technological change. Journal of Political Economy, 98(5):71-102.

Roodman, D. (2009). A note on the theme of too many instruments. Oxford Bulletin of Economics and Statistics, 71(1):135-158.

Roodman, D. (2009). How to do xtabond2: An introduction to difference and system GMM in Stata. The Stata Journal, 9(1):86-136.

Santos Silva, J. M. C., and Tenreyro S. (2006). "The Log of Gravity". Review of Economics and Statistics, 88(4):641-658.

Simon, J. (1977). The Economics of population growth. Princeton University Press.

Spilimbergo, A. (2009). Democracy and foreign education. The American Economic Review, $99(1): 528-543$.

Spolaore, E. and Wacziarg, R. (2009). The diffusion of development. Quarterly Journal of Eonomics, 124(2):469-529.

The World Bank. Global economic prospects 2008: Technology diffusion in the developing world. Washington, DC: The World Bank; 2008.

Tuccio, M. and Wahba, J. (2016). Can I have permission to leave the house? Return migration and the transfer of gender norms. IZA Discussion Paper 9216. 
Xu, B. (2010). The sophistication of exports: Is China special? China Economic Review, 21(3):482-493. 


\section{Appendix}

\section{Table A1: Main variables}

\begin{tabular}{|c|c|c|}
\hline Variable & Description & Definition and Source \\
\hline$E C I_{i, t}$ & $\begin{array}{l}\text { Economic Complexity } \\
\text { Index }\end{array}$ & $\begin{array}{l}\text { Measure of the knowledge in a society that gets translated into the products it } \\
\text { makes. Hausmann, Hidalgo, Bustos, Coscia, Chung, Jimenez, Simoes and Yildirim } \\
\text { (2011). }\end{array}$ \\
\hline$\overline{E C I}_{i, t}^{\rho}$ & $\begin{array}{l}\text { Average of the Eco- } \\
\text { nomic Complexity In- } \\
\text { dex at destination }\end{array}$ & $\begin{array}{l}\text { Weighted average of the Economic Complexity Index where the weights are re- } \\
\text { spectively emigration rates }(\rho=\phi) \text {, emigration shares }(\rho=S) \text {, import shares } \\
(\rho=I M P) \text {, inverse of geographical distances }(\rho=D I S) \text {, FDI shares }(\rho=F D I) \\
\text { inverse of genetic distance }(\rho=G E N) \text { and initial value in } 1980(\rho=I N I) \text {. Authors' } \\
\text { calculations. }\end{array}$ \\
\hline$M_{i, t}$ & Emigration rate $(\log )$ & $\begin{array}{l}\text { Proportion of migrants over the pre-migration population ( } 25 \text { years and older). } \\
\text { Brücker et al. (2013). }\end{array}$ \\
\hline$G D P_{i, t}$ & GDP per Capita & $\begin{array}{l}\text { Output-side real GDP per capita at current PPPs (in mil. } 2005 \text { US\$). Penn World } \\
\text { Table 8.0. }\end{array}$ \\
\hline$P_{o p}, t$ & $\begin{array}{l}\text { Total population } 25 \\
\text { years and older }\end{array}$ & Penn World Table 8.0. \\
\hline Hum $_{i, t}$ & Adult's Education & $\begin{array}{l}\text { Educational Attainment for Population Aged } 15 \text { and Over: Average Years of School- } \\
\text { ing Attained. Barro and Lee (2010). }\end{array}$ \\
\hline Trade $_{i, t}$ & Trade Openness & $\begin{array}{l}\text { Sum of exports and imports of goods and services measured as a share of gross } \\
\text { domestic product. World Development Indicators. }\end{array}$ \\
\hline$F D I_{i, t}$ & $\begin{array}{l}\text { Foreign Direct Invest- } \\
\text { ment }\end{array}$ & $\begin{array}{l}\text { Foreign Direct Investment, net inflows in current U.S. dollars. Foreign direct in- } \\
\text { vestment are the net inflows of investment to acquire a lasting management interest } \\
\text { (10 percent or more of voting stock) in an enterprise operating in an economy other } \\
\text { than that of the investor. World Development Indicators. }\end{array}$ \\
\hline & & Gravity model à la Feyrer (2009) \\
\hline $\log \left(\operatorname{Stock}_{i, j, t}\right)$ & $\begin{array}{l}\text { Bilateral migration } \\
\text { stock }(\log )\end{array}$ & $\begin{array}{l}\text { Stock of migrants from } i \text { residing in } j \text { at time } t \text {. Özden et al. (2011) and Brücker et } \\
\text { al. (2013). }\end{array}$ \\
\hline $\log \left(D_{i s t_{i, j}}\right)$ & Distance (log) & $\begin{array}{l}\text { Geographical distance between the biggest cities of the coutries } i \text { and } j \text { weighted by } \\
\text { the share of the city in the total population of the two countries. Head et al. (2010). }\end{array}$ \\
\hline $\operatorname{Bord}_{i, j}$ & Common border & $\begin{array}{l}\text { Dummy equal to } 1 \text { if countries } i \text { and } j \text { share a common border and } 0 \text { otherwise. } \\
\text { Head et al. (2010). }\end{array}$ \\
\hline Colony $_{i, j}$ & Colonial past & $\begin{array}{l}\text { Dummy equal to } 1 \text { if countries } i \text { and } j \text { share a colonial past and } 0 \text { otherwise. Head } \\
\text { et al. (2010). }\end{array}$ \\
\hline $\operatorname{Lang}_{i, j}$ & Common language & $\begin{array}{l}\text { Dummy equal to } 1 \text { if at least } 9 \% \text { in countries } i \text { and } j \text { populations speak a common } \\
\text { language and } 0 \text { otherwise. Head et al. (2010). }\end{array}$ \\
\hline
\end{tabular}


Figure A1: ECI for the 20 OECD destination countries available in Brücker et al. (2013) comparatively to the average ECI of other countries

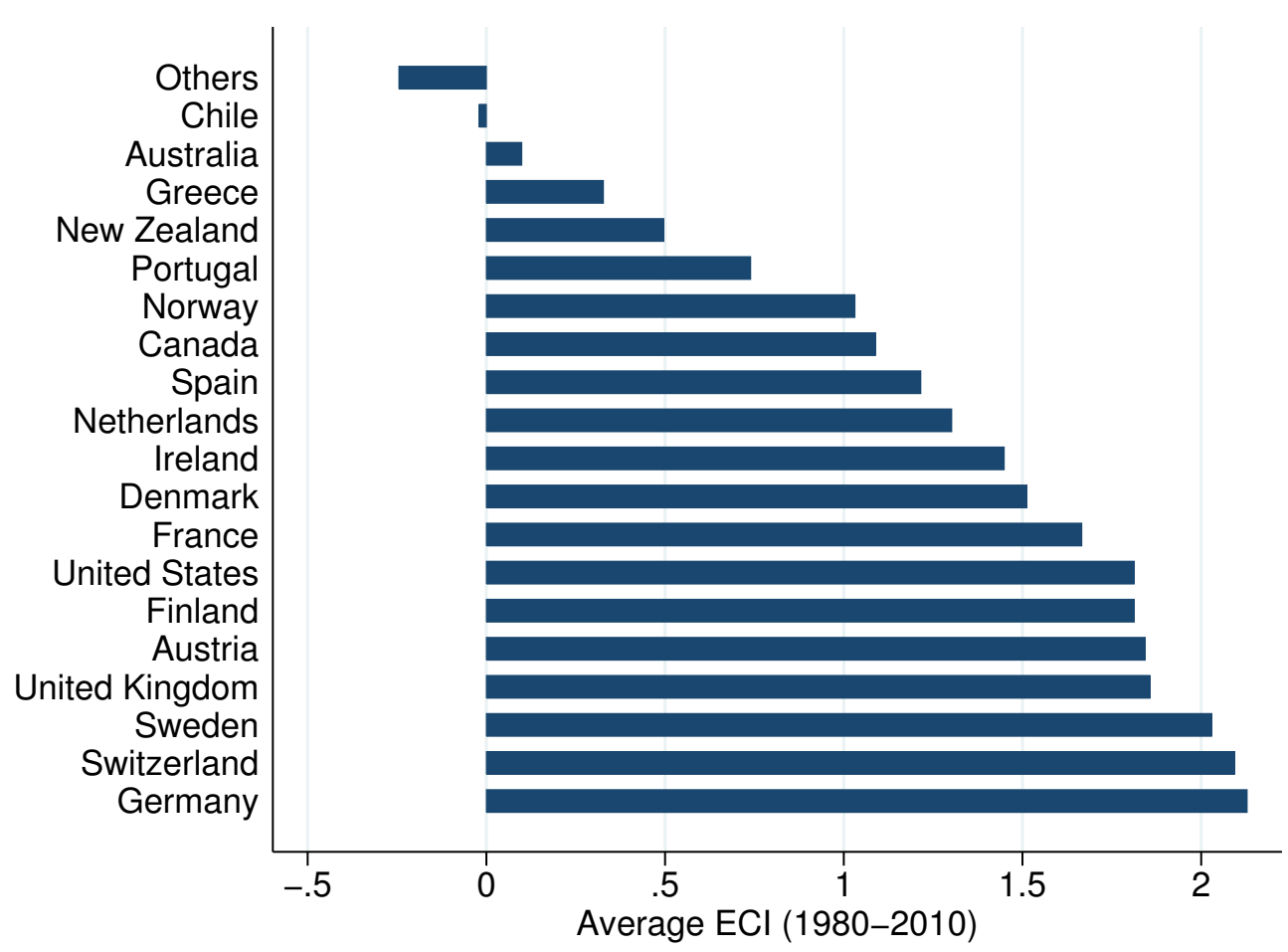

Source: Author's elaboration on Hausmann et al. (2011). 
Table A2: Countries in the sample

\begin{tabular}{|c|c|c|c|c|c|}
\hline Country & Observations & & & & \\
\hline \multicolumn{6}{|c|}{ Developed Countries (37) } \\
\hline Australia & 6 & Hungary & 4 & Portugal & \\
\hline Austria & 6 & Ireland & 6 & Qatar & \\
\hline Belgium & 2 & Israel & 6 & Saudi Arabia & \\
\hline Canada & 6 & Italy & 6 & Slovakia & \\
\hline China, Hong Kong SAR & 3 & Japan & 6 & Slovenia & \\
\hline Croatia & 3 & Korea & 6 & Spain & \\
\hline Czech Republic & 3 & Kuwait & 6 & Sweden & \\
\hline Denmark & 6 & Latvia & 3 & Switzerland & \\
\hline Estonia & 3 & Netherlands & 6 & Trinidad and Tobago & \\
\hline Finland & 6 & New Zealand & 6 & United Kingdom & \\
\hline France & 6 & Norway & 6 & United States & \\
\hline Germany & 3 & Oman & 6 & & \\
\hline Greece & 6 & Poland & 5 & & \\
\hline
\end{tabular}

\begin{tabular}{ll}
\hline Country & Observations \\
\hline
\end{tabular}

Developing Countries (83)

\begin{tabular}{|c|c|c|c|c|c|}
\hline Albania & 4 & Guinea-Bissau & 5 & Pakistan & 6 \\
\hline Angola & 5 & Honduras & 6 & Panama & 6 \\
\hline Argentina & 6 & India & 6 & Paraguay & 4 \\
\hline Azerbaijan & 3 & Indonesia & 6 & Peru & 6 \\
\hline Bangladesh & 6 & Iran & 5 & Philippines & 6 \\
\hline Belarus & 3 & Jamaica & 4 & Romania & 5 \\
\hline Bolivia & 6 & Jordan & 6 & Russia & 3 \\
\hline Bosnia and Herzegovina & 3 & Kazakhstan & 3 & Senegal & 6 \\
\hline Botswana & 1 & Kenya & 6 & South Africa & 6 \\
\hline Brazil & 6 & Kyrgyzstan & 3 & Sri Lanka & 6 \\
\hline Bulgaria & 5 & Laos & 6 & Sudan & 6 \\
\hline Cambodia & 4 & Lebanon & 2 & Syria & 5 \\
\hline Cameroon & 6 & Liberia & 3 & Tajikistan & 2 \\
\hline Chile & 6 & Lithuania & 3 & Tanzania & 5 \\
\hline China & 6 & Macedonia & 3 & Thailand & 6 \\
\hline Colombia & 6 & Madagascar & 6 & Tunisia & 6 \\
\hline Congo, Rep. of the & 6 & Malawi & 5 & Turkey & 6 \\
\hline Costa Rica & 6 & Malaysia & 6 & Turkmenistan & 3 \\
\hline Cote d'Ivoire & 6 & Mali & 5 & Uganda & 5 \\
\hline Dominican Republic & 6 & Mauritania & 6 & Ukraine & 3 \\
\hline Ecuador & 6 & Mauritius & 6 & Uruguay & 6 \\
\hline Egypt & 6 & Mexico & 6 & Uzbekistan & 3 \\
\hline El Salvador & 6 & Moldova & 3 & Venezuela & 6 \\
\hline Ethiopia & 4 & Mongolia & 4 & Vietnam & 5 \\
\hline Gabon & 6 & Morocco & 6 & Yemen & 2 \\
\hline Georgia & 3 & Mozambique & 6 & Zambia & 6 \\
\hline Ghana & 6 & Namibia & 1 & Zimbabwe & 6 \\
\hline Guatemala & 6 & Nigeria & 6 & & \\
\hline
\end{tabular}


Table A3: Alternative lags structures

\begin{tabular}{|c|c|c|c|c|c|c|c|c|c|c|c|c|c|c|c|}
\hline & $\begin{array}{c}(1) \\
E C I_{i, t}\end{array}$ & $\begin{array}{c}(2) \\
E C I_{i, t}\end{array}$ & $\begin{array}{c}(3) \\
E C I_{i, t}\end{array}$ & $\begin{array}{c}(4) \\
E C I_{i, t}\end{array}$ & $\begin{array}{c}(5) \\
E C I_{i, t}\end{array}$ & $\begin{array}{c}(6) \\
E C I_{i, t}\end{array}$ & $\begin{array}{c}(7) \\
E C I_{i, t}\end{array}$ & $\begin{array}{c}(8) \\
E C I_{i, t}\end{array}$ & $\begin{array}{c}(9) \\
E C I_{i, t}\end{array}$ & $\begin{array}{c}(10) \\
E C I_{i, t}\end{array}$ & $\begin{array}{c}(11) \\
E C I_{i, t}\end{array}$ & $\begin{array}{c}(12) \\
E C I_{i, t}\end{array}$ & $\begin{array}{c}(13) \\
E C I_{i, t}\end{array}$ & $\begin{array}{c}(14) \\
E C I_{i, t}\end{array}$ & $\begin{array}{c}(15) \\
E C I_{i, t}\end{array}$ \\
\hline$E C I_{i, t-5}$ & $\begin{array}{c}0.726^{* * *} \\
(0.000)\end{array}$ & $\begin{array}{c}0.700^{* * *} \\
(0.000)\end{array}$ & $\begin{array}{c}0.709^{* * *} \\
(0.000)\end{array}$ & $\begin{array}{c}0.736^{* * *} \\
(0.000)\end{array}$ & $\begin{array}{c}0.707^{* * *} \\
(0.000)\end{array}$ & $\begin{array}{c}0.720^{* * *} \\
(0.000)\end{array}$ & $\begin{array}{c}0.746^{* * *} \\
(0.000)\end{array}$ & $\begin{array}{c}0.709^{* * *} \\
(0.000)\end{array}$ & $\begin{array}{c}0.722^{* * *} \\
(0.000)\end{array}$ & $\begin{array}{c}0.736^{* * *} \\
(0.000)\end{array}$ & $\begin{array}{c}0.705^{* * *} \\
(0.000)\end{array}$ & $\begin{array}{c}0.716^{* * *} \\
(0.000)\end{array}$ & $\begin{array}{c}0.734^{* * *} \\
(0.000)\end{array}$ & $\begin{array}{c}0.703^{* * *} \\
(0.000)\end{array}$ & $\begin{array}{c}0.714^{* * * *} \\
(0.000)\end{array}$ \\
\hline$\overline{E C I}_{i, t-5}$ & $\begin{array}{c}0.970^{* *} \\
(0.038)\end{array}$ & $\begin{array}{c}1.072^{* * *} \\
(0.004)\end{array}$ & $\begin{array}{c}0.976^{* * *} \\
(0.005)\end{array}$ & $\begin{array}{c}0.906^{* *} \\
(0.035)\end{array}$ & $\begin{array}{c}0.977^{* * *} \\
(0.006)\end{array}$ & $\begin{array}{c}0.913^{* * *} \\
(0.004)\end{array}$ & $\begin{array}{l}0.791^{*} \\
(0.074)\end{array}$ & $\begin{array}{c}0.956^{* * *} \\
(0.006)\end{array}$ & $\begin{array}{c}0.952^{* * *} \\
(0.003)\end{array}$ & $\begin{array}{c}0.957^{* *} \\
(0.019)\end{array}$ & $\begin{array}{c}0.975^{* * *} \\
(0.003)\end{array}$ & $\begin{array}{c}0.994^{* * *} \\
(0.002)\end{array}$ & $\begin{array}{c}0.973^{* *} \\
(0.017)\end{array}$ & $\begin{array}{c}0.986^{* * *} \\
(0.003)\end{array}$ & $\begin{array}{c}0.983^{* * *} \\
(0.003)\end{array}$ \\
\hline $\log \left(G D P_{i, t}\right)$ & $\begin{array}{c}0.019 \\
(0.790)\end{array}$ & $\begin{array}{c}0.047 \\
(0.393)\end{array}$ & $\begin{array}{c}0.068 \\
(0.154)\end{array}$ & $\begin{array}{c}0.039 \\
(0.521)\end{array}$ & $\begin{array}{c}0.060 \\
(0.247)\end{array}$ & $\begin{array}{l}0.078^{*} \\
(0.092)\end{array}$ & $\begin{array}{c}0.048 \\
(0.379)\end{array}$ & $\begin{array}{c}0.071 \\
(0.163)\end{array}$ & $\begin{array}{l}0.079^{*} \\
(0.079)\end{array}$ & $\begin{array}{c}0.042 \\
(0.448)\end{array}$ & $\begin{array}{c}0.067 \\
(0.185)\end{array}$ & $\begin{array}{c}0.074 \\
(0.106)\end{array}$ & $\begin{array}{c}0.042 \\
(0.451)\end{array}$ & $\begin{array}{c}0.068 \\
(0.182)\end{array}$ & $\begin{array}{c}0.075 \\
(0.110)\end{array}$ \\
\hline $\log \left(\operatorname{Pop}_{i, t}\right)$ & $\begin{array}{c}0.094^{* *} \\
(0.011)\end{array}$ & $\begin{array}{c}0.110^{* * *} \\
(0.000)\end{array}$ & $\begin{array}{c}0.115^{* * * *} \\
(0.000)\end{array}$ & $\begin{array}{c}0.097^{* * *} \\
(0.007)\end{array}$ & $\begin{array}{c}0.120^{* * *} \\
(0.000)\end{array}$ & $\begin{array}{c}0.120^{* * *} \\
(0.000)\end{array}$ & $\begin{array}{c}0.104^{* * * *} \\
(0.004)\end{array}$ & $\begin{array}{c}0.126^{* * * *} \\
(0.000)\end{array}$ & $\begin{array}{c}0.124^{* * *} \\
(0.000)\end{array}$ & $\begin{array}{c}0.108^{* * * *} \\
(0.003)\end{array}$ & $\begin{array}{c}0.124^{* * *} \\
(0.000)\end{array}$ & $\begin{array}{c}0.126^{* * * *} \\
(0.000)\end{array}$ & $\begin{array}{c}0.108^{* * *} \\
(0.003)\end{array}$ & $\begin{array}{c}0.124^{* * *} \\
(0.000)\end{array}$ & $\begin{array}{c}0.125^{* * *} \\
(0.000)\end{array}$ \\
\hline $\log \left(\operatorname{Trade}_{i, t}\right)$ & $\begin{array}{l}-0.150 \\
(0.146)\end{array}$ & $\begin{array}{c}-0.086 \\
(0.290)\end{array}$ & $\begin{array}{l}-0.047 \\
(0.509)\end{array}$ & $\begin{array}{l}-0.117 \\
(0.176)\end{array}$ & $\begin{array}{l}-0.054 \\
(0.477)\end{array}$ & $\begin{array}{l}-0.022 \\
(0.742)\end{array}$ & $\begin{array}{l}-0.099 \\
(0.226)\end{array}$ & $\begin{array}{l}-0.042 \\
(0.569)\end{array}$ & $\begin{array}{l}-0.029 \\
(0.675)\end{array}$ & $\begin{array}{l}-0.106 \\
(0.205)\end{array}$ & $\begin{array}{l}-0.050 \\
(0.504)\end{array}$ & $\begin{array}{c}-0.031 \\
(0.640)\end{array}$ & $\begin{array}{c}-0.107 \\
(0.199)\end{array}$ & $\begin{array}{l}-0.052 \\
(0.485)\end{array}$ & $\begin{array}{l}-0.035 \\
(0.602)\end{array}$ \\
\hline Hum $_{i, t}$ & $\begin{array}{c}0.080^{* * *} \\
(0.006)\end{array}$ & $\begin{array}{c}0.076^{* * *} \\
(0.001)\end{array}$ & $\begin{array}{c}0.064^{* * *} \\
(0.003)\end{array}$ & $\begin{array}{c}0.068^{* * *} \\
(0.009)\end{array}$ & $\begin{array}{c}0.070^{* * *} \\
(0.001)\end{array}$ & $\begin{array}{c}0.058^{* * *} \\
(0.005)\end{array}$ & $\begin{array}{c}0.062^{* *} \\
(0.014)\end{array}$ & $\begin{array}{c}0.064^{* * *} \\
(0.003)\end{array}$ & $\begin{array}{c}0.056^{* * *} \\
(0.009)\end{array}$ & $\begin{array}{c}0.066^{* * *} \\
(0.008)\end{array}$ & $\begin{array}{c}0.067^{* * *} * \\
(0.002)\end{array}$ & $\begin{array}{c}0.059^{* * *} \\
(0.009)\end{array}$ & $\begin{array}{c}0.066^{* * *} \\
(0.008)\end{array}$ & $\begin{array}{c}0.067^{* * *} \\
(0.002)\end{array}$ & $\begin{array}{c}0.059^{* * *} \\
(0.008)\end{array}$ \\
\hline$F D I_{i, t}$ & $\begin{array}{l}0.012^{*} \\
(0.081)\end{array}$ & $\begin{array}{c}0.008 \\
(0.213)\end{array}$ & $\begin{array}{c}0.003 \\
(0.641)\end{array}$ & $\begin{array}{c}0.010 \\
(0.163)\end{array}$ & $\begin{array}{c}0.007 \\
(0.284)\end{array}$ & $\begin{array}{c}0.002 \\
(0.759)\end{array}$ & $\begin{array}{c}0.010 \\
(0.145)\end{array}$ & $\begin{array}{c}0.007 \\
(0.271)\end{array}$ & $\begin{array}{c}0.002 \\
(0.781)\end{array}$ & $\begin{array}{c}0.010 \\
(0.165)\end{array}$ & $\begin{array}{c}0.007 \\
(0.250)\end{array}$ & $\begin{array}{c}0.002 \\
(0.708)\end{array}$ & $\begin{array}{c}0.010 \\
(0.164)\end{array}$ & $\begin{array}{c}0.007 \\
(0.259)\end{array}$ & $\begin{array}{c}0.002 \\
(0.749)\end{array}$ \\
\hline Nb. Lags $E C I_{i, t-5}$ & 1 & 1 & 1 & 2 & 2 & 2 & 3 & 3 & 3 & 4 & 4 & 4 & 5 & 5 & 5 \\
\hline Nb. Lags Endogenous Var. & 2 & 3 & 4 & 2 & 3 & 4 & 2 & 3 & 4 & 2 & 3 & 4 & 2 & 3 & 4 \\
\hline Observations & 600 & 600 & 600 & 600 & 600 & 600 & 600 & 600 & 600 & 600 & 600 & 600 & 600 & 600 & 600 \\
\hline Nb. countries & 120 & 120 & 120 & 120 & 120 & 120 & 120 & 120 & 120 & 120 & 120 & 120 & 120 & 120 & 120 \\
\hline Nb. instruments & 74 & 97 & 114 & 78 & 101 & 118 & 81 & 104 & 121 & 83 & 106 & 123 & 84 & 107 & 124 \\
\hline Country fixed effects & Yes & Yes & Yes & Yes & Yes & Yes & Yes & Yes & Yes & Yes & Yes & Yes & Yes & Yes & Yes \\
\hline Year fixed effects & Yes & Yes & Yes & Yes & Yes & Yes & Yes & Yes & Yes & Yes & Yes & Yes & Yes & Yes & Yes \\
\hline $\operatorname{AR}(1)$ & 0.000 & 0.000 & 0.000 & 0.000 & 0.000 & 0.000 & 0.000 & 0.000 & 0.000 & 0.000 & 0.000 & 0.000 & 0.000 & 0.000 & 0.000 \\
\hline $\operatorname{AR}(2)$ & 0.407 & 0.434 & 0.444 & 0.423 & 0.455 & 0.451 & 0.430 & 0.456 & 0.447 & 0.430 & 0.452 & 0.449 & 0.430 & 0.451 & 0.447 \\
\hline Hansen'J (p-value) & 0.187 & 0.173 & 0.298 & 0.140 & 0.190 & 0.298 & 0.168 & 0.210 & 0.337 & 0.212 & 0.251 & 0.408 & 0.237 & 0.278 & 0.433 \\
\hline
\end{tabular}

country level. The lagged dependent variable is treated as predetermined. All other variables are treated as endogenous. 
Table A4: Gravity model à la Feyrer (2009)

\begin{tabular}{|c|c|}
\hline & $\begin{array}{c}(1) \\
\log \left(\text { Stock }_{i, j, t}\right)\end{array}$ \\
\hline $\log \left(\right.$ Dist $\left._{i, j}\right) \times I_{1980}$ & $\begin{array}{c}-0.844^{* * *} \\
(0.000)\end{array}$ \\
\hline $\log \left(\right.$ Dist $\left._{i, j}\right) \times I_{1985}$ & $\begin{array}{c}-0.759^{* * *} \\
(0.000)\end{array}$ \\
\hline $\log \left(\right.$ Dist $\left._{i, j}\right) \times I_{1990}$ & $\begin{array}{c}-0.741^{* * *} \\
(0.000)\end{array}$ \\
\hline $\log \left(\operatorname{Dist}_{i, j}\right) \times I_{1995}$ & $\begin{array}{c}-0.738^{* * * *} \\
(0.000)\end{array}$ \\
\hline $\log \left(D_{i s t_{i, j}}\right) \times I_{2000}$ & $\begin{array}{c}-0.729 * * * \\
(0.000)\end{array}$ \\
\hline $\log \left(\right.$ Dist $\left._{i, j}\right) \times I_{2005}$ & $\begin{array}{c}-0.689^{* * *} \\
(0.000)\end{array}$ \\
\hline $\log \left(\right.$ Dist $\left._{i, j}\right) \times I_{2010}$ & $\begin{array}{c}-0.690 * * * \\
(0.000)\end{array}$ \\
\hline $\operatorname{Bord}_{i, j}$ & $\begin{array}{c}0.357 \\
(0.148)\end{array}$ \\
\hline $\operatorname{Lang}_{i, j}$ & $\begin{array}{c}1.215^{* * *} \\
(0.218)\end{array}$ \\
\hline Colony $_{i, j}$ & $\begin{array}{c}1.200^{* * *} \\
(0.218)\end{array}$ \\
\hline Constant & $\begin{array}{c}11.624^{* * * *} \\
(0.000)\end{array}$ \\
\hline Observations & 26600 \\
\hline $\mathrm{Nb}$. origin & 191 \\
\hline Nb. destination & 20 \\
\hline R-squared & 0.792 \\
\hline Year dummies & Yes \\
\hline Origin dummies & Yes \\
\hline Destination dummies & Yes \\
\hline $\begin{array}{l}\text { Source: Author's elal } \\
\text { Brücker et al. }(2013) \\
\text { in parentheses }(* * * \mathrm{p} \\
\text { errors are clustered at } \\
\text { great-circle distance b } \\
\text { is a dummy variable e } \\
\text { border. } \text { Lang }_{i, j} \text { is a d } \\
9 \% \text { of the populations } \\
\text { Colony } y_{i, j} \text { is a dummy } \\
\text { colonial past. }\end{array}$ & $\begin{array}{l}\text { Hausmann et al. (2011), } \\
\text { al. }(2010) \text {. Notes: pvalues } \\
0.05, * \mathrm{p}<0.1) \text {. Standard } \\
\text {-pair level. Dist } t_{i, j} \text { is the } \\
\text { apitals of } i \text { and } j . \text { Bord }_{i, j} \\
\mathrm{f} i \text { and } j \text { share a common } \\
\text { ole equal to one if at least } \\
\text { peak a common language. } \\
\text { al to one if } i \text { and } j \text { share a }\end{array}$ \\
\hline
\end{tabular}

